\title{
De etterlatte ved hendelsesbaserte tilsyn av dødsfall- en evaluering
}

\author{
Evalueringsrapport av prosjektet \\ 'Styrket involvering av pasienter, brukere og pårørende i tilsyn - de \\ etterlatte ved hendelsesbaserte tilsyn av dødsfall'
}

Av:

Lene Schibevaag

Cecilie Haraldseid-Driftland

Rannveig Tvete Zachrisen

Siri Wiig

\section{$\backsim$ SHARE}

Universitetet i Stavanger 


\section{Innhold}

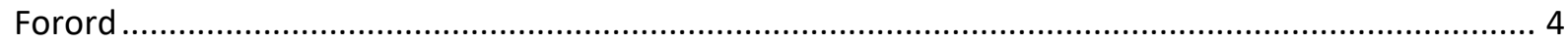

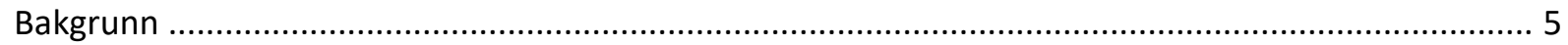

'De etterlatte ved hendelsesbaserte tilsyn av d $\varnothing$ dsfall' ..................................................................... 5

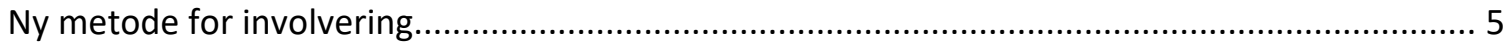

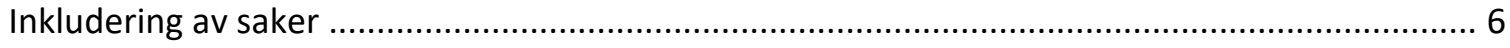

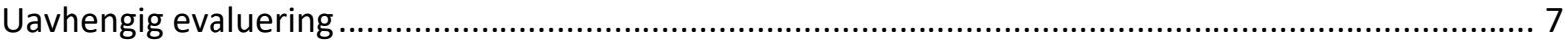

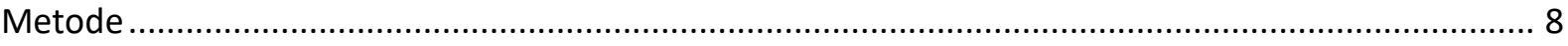

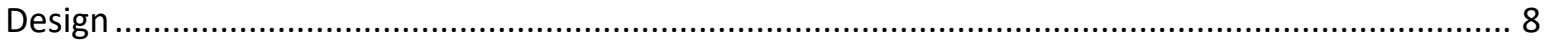

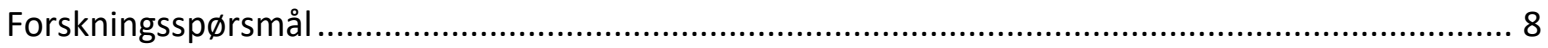

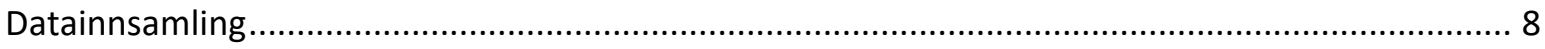

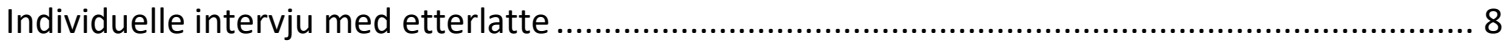

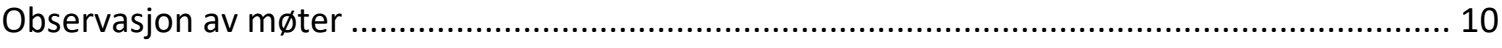

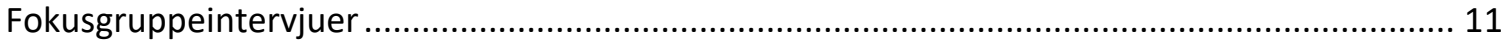

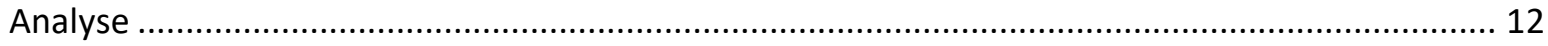

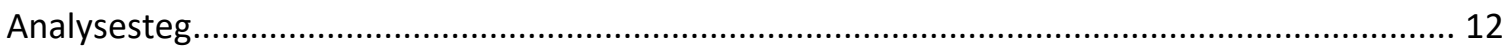

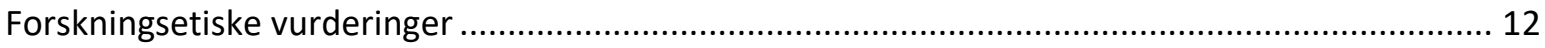

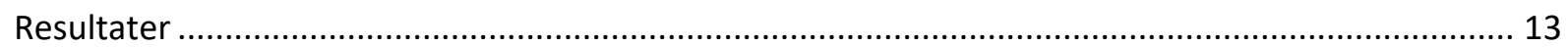

Etterlattes opplevelser av møtet med fylkesmannen .................................................................. 13

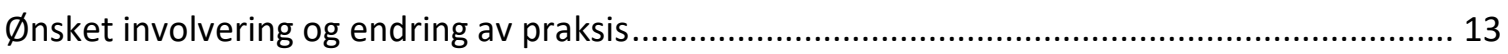

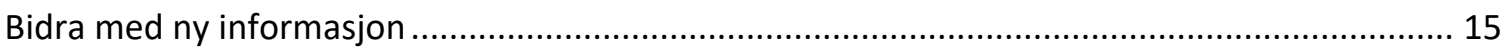

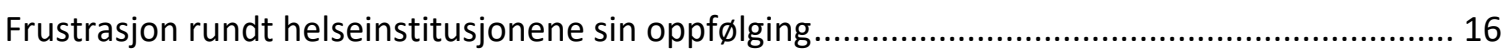

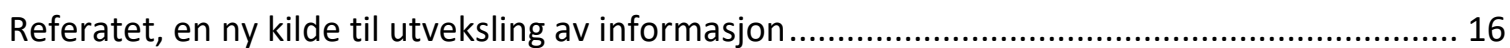

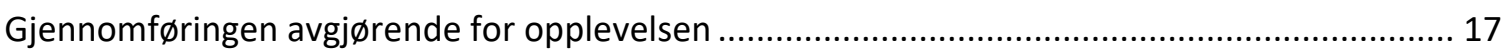

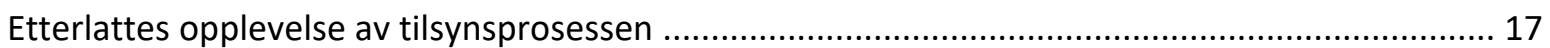

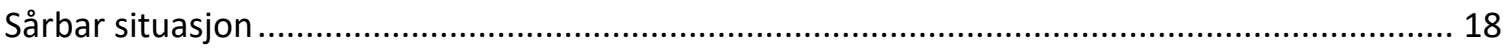

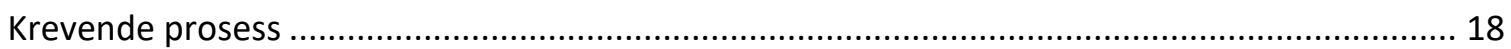

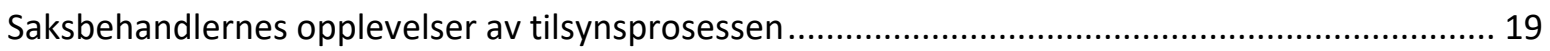

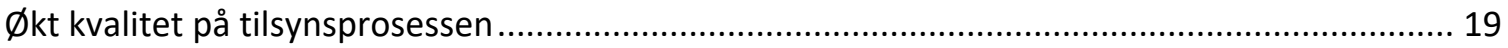

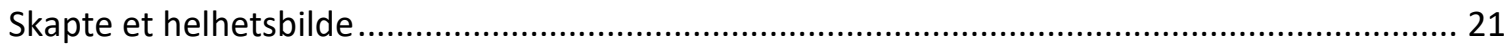

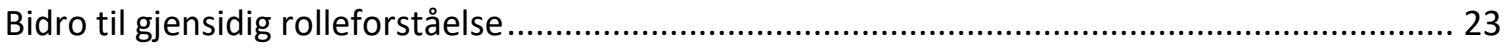

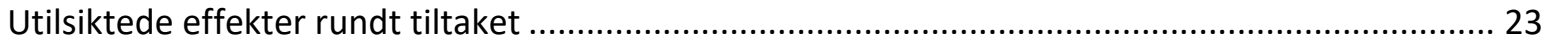

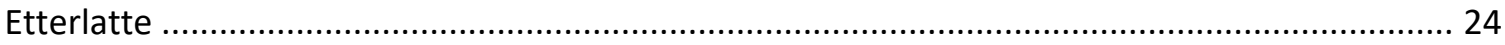

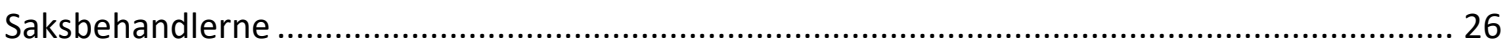

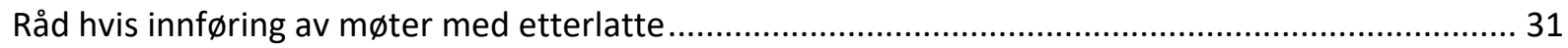

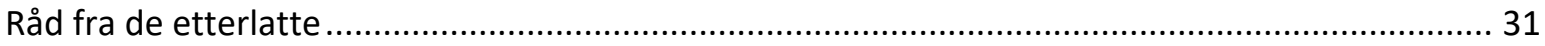


Sentrale personlige egenskaper og kompetanse hos fylkesmannens ansatte

Hvordan ivareta etterlatte som er involvert i en tilsynssak? .................................................... 33

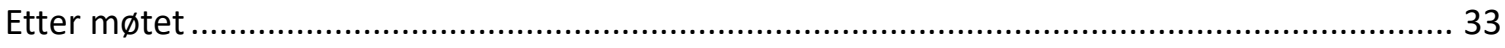

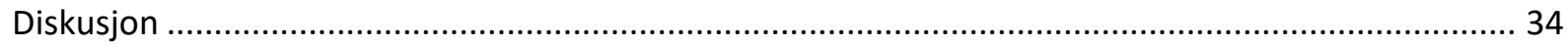

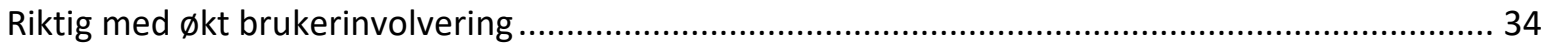

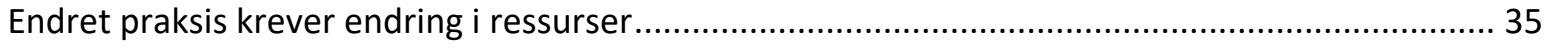

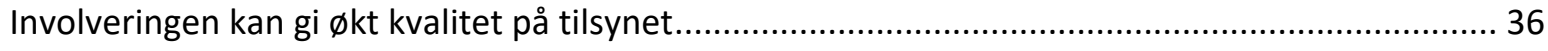

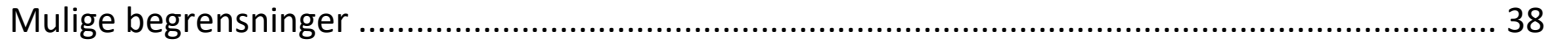

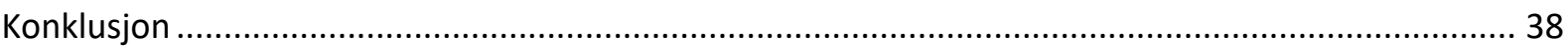

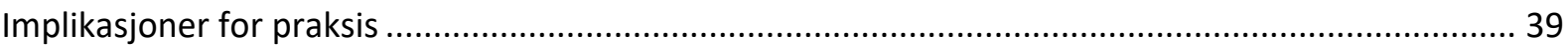

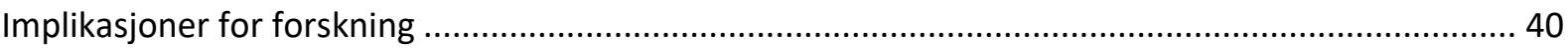

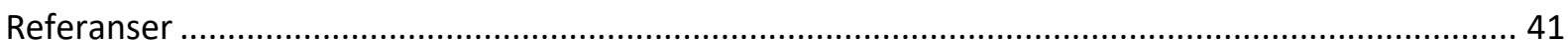




\section{Forord}

Universitetet i Stavanger (UiS), ved Senter for kvalitet og sikkerhet i helsetjenesten (SHARE), overleverer herved endelig sluttrapport for prosjektet: De etterlatte ved hendelsesbaserte tilsyn av dødsfall - en evaluering.

Vi ønsker å takke for oppdraget og et meget godt samarbeid med fylkesmannen. Vi ønsker å takke alle etterlatte som stilte opp. De etterlatte lot oss delta på møter som observatør, og fortale oss om sine opplevelser i møte med fylkesmannen i en tøff tid, etter at de hadde mistet en person de hadde nær i et uventet dødsfall. I prosjektet stilte også saksbehandlere hos fylkesmannen opp og delte sine forventninger, erfaringer og vurderinger av involvering av etterlatte $\mathrm{i}$ hendelsesbaserte tilsyn. Dette er vi også takknemlige for. Prosjektleder hos fylkesmannen Einar Hannisdal, inviterte UiS og SHARE med på prosjektutviklingen og søknad til Statens helsetilsyn (Helsetilsynet). Hannisdal har hatt en sentral rolle i samarbeidet relatert til rekruttering, organiseringen av datainnsamling og diskusjon om resultater og implikasjoner. Anbefalinger og resultater presentert i rapporten står UiS og SHARE ansvarlige for, men vi ønsker å takke prosjektleder hos fylkesmannen for den viktige rollen han har hatt for gjennomføringen av evalueringen.

Samlet sett har dette arbeidet pågått i nesten to år og vi takker for tilliten alle har vist oss. For UiS og SHARE er dette et betydningsfullt oppdrag for å bidra til oppbygning av et viktig forskningsfelt, samtidig som det er sentralt for en kunnskapsbasert utvikling av tilsynsmetoder og praksis.

Vi håper rapporten, resultatene, råd og forslag til videre praksis og forskning kan komme til nytte for de det måtte angå.

Stavanger, 5.2

Siri Wiig

Prosjektleder og professor i kvalitet og sikkerhet i helsestjenesten, SHARE -Senter for kvalitet og sikkerhet i helsesystemer, Universitetet i Stavanger. 


\section{Bakgrunn}

Det har i flere år blitt rettet kritikk mot at pasienter, brukere og pårørende har hatt for liten involvering i tilsynsaktiviteter generelt og i oppfølging av alvorlige hendelser $\mathrm{i}$ helsetjenesten spesielt [1-7]. En overordnet målsetting fra tilsynsmyndighetene er derfor å styrke involvering av etterlatte i tilsynssaker samt å ta i bruk de etterlatte og pårørende sine erfaringer som en ressurs for å utvikle brukerperspektivet i norsk tilsynspraksis $[5,8]$.

Involvering av pårørende for å øke pasientsikkerheten i ulike pasientsettinger har ved flere tilfeller vist seg å være svært betydningsfullt $[9,10]$. Pårørende har ofte inngående kunnskap om pasienten over tid og har sett endringer og vært delaktig i dialogen med helsetjenesten.

Det finnes eksempler på brukerinvolvering i tilsyn i form av spørreundersøkelser, i tilsynsteam eller som lekpersoner $[11,12,24]$. Kunnskapen om hvordan pårørende kan involveres $\mathrm{i}$ tilsynssaker i de mest alvorlige hendelsene er derimot mangelfull [13]. Som et resultat av dette har et norsk fylkesmannsembete startet opp prosjektet 'De etterlatte ved hendelsesbaserte tilsyn av dødsfall'. Prosjektet har mottatt stimuleringsmidler fra Statens helsetilsyn (Helsetilsynet) i forbindelse med utlysningen 'Styrket involvering av pasienter, brukere og pårørende i tilsyn'.

\section{'De etterlatte ved hendelsesbaserte tilsyn av dødsfall'}

Vanlig saksgang i tilsynssaker hos fylkesmannen er skriftlig. Det vil si at fylkesmannen henter inn dokumentasjon fra involverte helseinstitusjoner og helsepersonell. På bakgrunn av denne dokumentasjonen avgjør fylkesmannen om det har forekommet en svikt i helsehjelpen som er gitt sett i lys av gjeldene norsk helselovgiving og hva som ansees som 'god praksis'.

Nærmeste pårørende til avdøde har innsikt i all skriftlig dokumentasjon i selve tilsynssaken og får informasjon om sakens gang og får spesielt anledning til å kommentere innsendt dokumentasjon og uttalelser fra påklagd helsetjeneste. Utover dette er det ikke vanlig praksis at de etterlatte blir involvert i de ulike tilsynssakene.

\section{Ny metode for involvering}

Prosjektet 'De etterlatte ved hendelsesbaserte tilsyn av dødsfall' har handlet om å endre saksbehandlingsrutiner ved oppfølging av uventede dødsfall. Rutiner ble endret fra å behandle sakene gjennom skriftlig informasjonsutveksling med de involverte institusjonene, til også å invitere etterlatte fra de utvalgte dødsfallene i prosjektet, til et møte. Hovedhensikten med møtet var å belyse hendelsesforløpet fra de etterlattes perspektiv og dermed å se om informasjonen fra de etterlatte bedre kunne belyse selve tilsynssaken. 
De etterlatte ble invitert til møtet via brev fra fylkesmannen hvor de mottok skriftlig informasjon om prosjektet, samt en samtykkeerklæring som de måtte signere for å kunne delta. I møtet med de etterlatte var det to representanter tilstede fra fylkesmannen. En prosjektleder/ass.fylkeslege som hadde medisinskfaglig bakgrunn som overlege, samt en jurist som var saksbehandler hos fylkesmannen. Prosjektleder og saksbehandler gjennomførte et kort 'formøte' sammen før de etterlatte kom inn i møterommet. Hensikten med denne korte samtalen dem imellom var å kunne samstemme generelle oppfatninger om hendelsesforløpet i saken, kort diskutere uenigheter, spørsmål eller ulike oppfatninger om saken som eventuelt burde inngå i spørsmål til de etterlatte.

De etterlatte kunne komme til møtet alene, sammen med andre familiemedlemmer, venner, representant fra pasient- og brukerorganisasjon eller annen juridisk bistand. Møtet var satt opp til å vare i ca. to timer. Innledningsvis informerte prosjektleder om hensikten med møtet og at tilsynsmyndigheten ikke skulle konkludere utfallet av selve tilsynssaken i møtet. De etterlatte ble også spurt om hvordan de opplevde tiden før dødsfallet og viktige hendelser som kunne belyse dødsfallet. I møtet ble de etterlatte oppfordret til å beskrive hendelsesforløpet kronologisk. Prosjektleder og saksbehandler forsøkte å ikke avbryte, men ventet til etter redegjørelsen fra den/de etterlatte med å stille oppklarende spørsmål som ble notert underveis.

De etterlatte ble også informert om den videre gangen i selve tilsynssaken og at de i etterkant av møtet ville få tilsendt et referat fra møtet hos fylkesmannen, som de kunne kommentere på dersom de syntes at referatet trengte oppklaringer.

\section{Inkludering av saker}

Fylkesmannen har inkludert 50 dødsfall i prosjekt fra 2017-2018. De fordelte seg på tre ulike seksjoner i helseavdelingen hos fylkesmannen som følger:

- Somatisk spesialisthelsetjeneste: 23 saker

- Kommunehelsetjeneste: 15 saker

- Rus og psykiatri: 12 saker

○ Dødsfall avgrenset til selvmord

Dødsfallene som ble inkludert i prosjektet ble utvalgt etter følgende kriterier:

Inklusjons kriterier:

- Uventet dødsfall, uklare omstendigheter og/eller mulig svikt

○ Klage fra etterlatte, varselsaker fra Helsetilsynet, oversendelser fra politiet 
○ Etterlatte ba om et møte i etablert sak

Eksklusjons kriterier:

○ Dødsfallet hadde skjedd $>12$ måneder før fylkesmannen mottok saken

- Årsaksforhold var helt avklart eller de etterlatte kunne av praktiske eller tekniske årsaker ikke belyse hendelsesforløpet, f.eks. var ikke tilstede i kritiske faser

○ Uklarheter knyttet til hvem som var nærmeste etterlatte til avdøde

- De etterlatte bodde i en annen helseregion

○ Fylkesmannen hadde ikke kapasitet til å ta saken inn i prosjektet

○ Fylkesmannen var inhabil

○ Saken var på grunn av alvorlighet oversendt Helsetilsynet etter kort tid

○ Det var startet politietterforskning

\section{Uavhengig evaluering}

'Senter for kvalitet og sikkerhet i helsetjenesten' (SHARE) fra Universitetet i Stavanger (UiS) ble den 01.06.2017 engasjert for å gjøre en evaluering av det aktuelle tiltaket som møtet representerer. Evalueringen har fra SHARE sin side resultert i denne rapporten som beskriver SHARE sin uavhengige evaluering av prosjektet til fylkesmannen.

I kontrakten mellom partene er det avtalt at evalueringen skal dekke følgende punkter;

- Hvordan gjennomførte fylkesmannen møtene med etterlatte?

- Hvordan opplevde de etterlatte prosessen?

- Utilsiktede effekter for etterlatte og fylkesmannen

- Råd hvis innføring av møter i senere praksis, internt og ved andre fylkesmannembeter

- Hvordan kan de etterlattes erfaringer bidra til å utvikle brukerperspektivet i norsk tilsynspraksis?

Evalueringen har i så måte tre hovedfokusområder 1) gjennomføringen av møte i seg selv, 2) saksbehandlernes erfaringer rundt møtet og 3) de pårørendes erfaringer rundt møtet. Det ble avtalt at de respektive områdene skulle evalueres igjennom forskningsaktivitet $\mathrm{i}$ form av deltagelse på 10 utvalgte av fylkesmannens 50 møter med etterlatte, ett oppfølgingsmøte med 20 familier/etterlatte, og gjennomføring av tre fokusgruppeintervju med saksbehandlere, (oppstartefase, midtveis og ved slutten av prosjektet). 
Fylkesmannen organiserte møtene og etablerte møteavtaler med de etterlatte som en del av sin saksbehandling i disse sakene. Alle involverte mottok informasjon i forkant av møtene og samtykket til at UiS kunne delta.

\section{Metode}

\section{Design}

Evalueringen er foretatt som en kvalitativ prosess evaluering basert på Patton [14]. For å styrke resultatene og besvare de ulike forskningsspørsmålene har evalueringen benyttet metodetriangulering ved bruk av både individuelle intervjuer, observasjonsdata, og fokusgruppeintervju.

\section{Forskningsspørsmål}

SHARE har evaluert tiltaket ut i fra følgende forskningsspørsmål:

- Hvordan gjennomførte fylkesmannen møtene med etterlatte?

- Hvordan opplevde de etterlatte og saksbehandlerne prosessen?

- Oppstod det utilsiktede effekter for etterlatte og fylkesmannen?

- Hvilke råd gir de etterlatte dersom møtene innføres senere i praksis, internt og hos andre fylkesmenn?

- Hvordan kan de etterlattes erfaringer bidra til å utvikle brukerperspektivet i norsk tilsynspraksis?

\section{Datainnsamling}

Datainnsamlingen har foregått over en ni måneders periode mellom 2017 og 2018. Innsamlingen har i hovedsak blitt foretatt av en forsker, i det videre omtalt som hovedforsker. Ytterligere tre forskere har bidratt til deler av datainnsamlingen samt analyser og utarbeidelse av rapporten.

\section{Individuelle intervju med etterlatte}

Det ble gjennomført intervjuer med etterlatte fra 18 ulike tilsynssaker og totalt 29 etterlatte ble intervjuet. Et fåtall familier ble ikke tilbudt å være med på individuelle intervju på bakgrunn av prosjektleders vurdering om at det kunne være for krevende ut i fra deres situasjon. Deltagerne som ble spurt om å delta på individuelle intervju, fikk tilbud om å ha med seg en selvvalgt støttespiller under intervjuet, ettersom det å snakke om hendelsen kunne oppleves som en påkjenning. Ti av de etterlatte valgte å ha med seg nære venner, familiemedlemmer eller 
representant fra pasient og bruker organisasjoner. I de resterende åtte intervjuene kom den etterlatte til intervjuet alene (se tabell 1).

Alle intervjuene ble foretatt ved bruk av en semi-strukturert intervjuguide (vedlegg I). Intervjuene hadde en varighet på en til to timer, ble tatt opp på bånd og skrevet ut i etterkant. Hovedformålet med det semi-strukturerte intervjuet var å få belyst de etterlattes perspektiv på tiltaket som møtet hos fylkesmannen representerer for å forbedre eventuelle fremtidige lignende tiltak. Alle intervjuene ble gjennomført med de etterlatte før sakene deres var konkludert slik at konklusjonen i saken ikke skulle påvirke deres vurdering av møtet de hadde deltatt på.

Tabell 1. Oversikt over deltagere i individuelle intervju

\begin{tabular}{|c|c|c|c|}
\hline Intervju nr. & $\begin{array}{l}\text { Antall etterlatte og deres } \\
\text { relasjon til den avd } \varnothing \text { de }\end{array}$ & Kort beskrivelse av hendelsen & $\begin{array}{l}X=\text { både intervju } \\
\text { og observasjon }\end{array}$ \\
\hline 1 & 2 (mor og far) & $\begin{array}{l}\text { Pasient med omfattende behov funnet } \mathrm{d} \varnothing \mathrm{d} \text { i sengen } \\
\text { på sykehuset. }\end{array}$ & \\
\hline 2 & 2 (mor og tante) & $\begin{array}{l}\text { Kvinne begikk selvmord samme dag som utskrivelse } \\
\text { fra psykiatrisk avdeling. }\end{array}$ & \\
\hline 3 & 1 (kone) & $\begin{array}{l}\text { Mann d } \varnothing \text { de av hjerneblødning, historie med tiltagende } \\
\text { symptomer, mange aktører involvert. }\end{array}$ & $\mathrm{x}$ \\
\hline 4 & 1 (kusine) & $\begin{array}{l}\text { Ung kvinne med demens forflyttet fra sykehjem til } \\
\text { sykehus. Manglende informasjon til pårørende om at } \\
\text { hun var på et terminalt stadium. }\end{array}$ & \\
\hline 5 & 2 (kone og datter) & $\begin{array}{l}\text { Kvinne død under uklare omstendigheter etter } \\
\text { fjerning av pacemaker. }\end{array}$ & \\
\hline 6 & 3 (mor, søster og tante) & $\begin{array}{l}\text { Ung kvinne døde etter cellegift. Pårørende reiste } \\
\text { spørsmål om en mulig genetisk feil som kunne } \\
\text { resultere i at hun var intolerant for denne type } \\
\text { medisin. }\end{array}$ & \\
\hline 7 & 2 (kone og fetter) & $\begin{array}{l}\text { Mann døde etter tarmslyng, mulig diagnostisk } \\
\text { forsinkelse på det lokale sykehuset. }\end{array}$ & \\
\hline 8 & 1 (mor) & $\begin{array}{l}\text { Ung kvinne } d \varnothing d \text { etter omfattende kreftkirurgi, mulig } \\
\text { diagnostisk forsinkelse. }\end{array}$ & $\mathrm{x}$ \\
\hline 9 & 1 (partner) & $\begin{array}{l}\text { Mann ble raskt forverret } \mathrm{i} \text { tilstanden og } \mathrm{d} \varnothing \mathrm{de} \text { etter } \\
\text { overflytting fra intensivavdelingen til sengepost. }\end{array}$ & \\
\hline 10 & 1 (bror) & $\begin{array}{l}\text { Mann } d \varnothing d e \text { av hjerteinfarkt, mulig sen respons fra } \\
\text { ambulansetjenesten. }\end{array}$ & $\mathrm{x}$ \\
\hline 11 & 2 (mor og far) & Ung kvinne døde etter hjerneblødning under trening. & \\
\hline 12 & 2 (kone og datter) & $\begin{array}{l}\text { Mann funnet } d \varnothing d \text { på parkeringsplass. Uoppdaget } \\
\text { hjerteproblematikk ved nylig fastlegebes } \varnothing \mathrm{k} \text {. }\end{array}$ & $\mathrm{x}$ \\
\hline 13 & 1 (kone) & Mann døde av kreft, mulig manglende oppfølging. & \\
\hline 14 & 2 (far og gudmor) & $\begin{array}{l}\text { Mann begikk selvmord etter tre møter med psykolog } \\
\text { på det lokale psykiatriske sykehuset. }\end{array}$ & \\
\hline 15 & 1 (datter) & $\begin{array}{l}\text { Kvinnelig beboer på sykehjem døde etter fall fra } \\
\text { sengen. }\end{array}$ & \\
\hline 16 & 1 (mor) & $\begin{array}{l}\text { Mann døde av overdose under innleggelse på en } \\
\text { psykiatrisk avdeling. }\end{array}$ & \\
\hline 17 & 2 (mor og storebror) & $\begin{array}{l}\text { Ung mann begikk selvmord da han var innlagt på } \\
\text { lukket psykiatrisk avdeling. }\end{array}$ & $\mathrm{x}$ \\
\hline 18 & 2 (datter og venn av familien) & Kvinne døde av kreft, mulig manglende oppfølging. & \\
\hline Totalt & 29 & & 5 \\
\hline
\end{tabular}




\section{Observasjon av møter}

Deltakerne på møtene besto av fylkesmannen representert ved prosjektleder (lege) og en eller to saksbehandlere (jurister) og i mellom 1-3 etterlatte og/eller pårørende. Alle de etterlatte hadde i innkallelsesbrevet fått tilbud om å ha med seg en selvvalgt støttespiller. Det var kun to av de etterlatte som kom til de observerte møtene alene (Tabell 2). Etter flere diskusjoner i både referanse- og styringsgruppe var prosjektleder møteleder for alle 50 møtene. Prosjektleder laget etter hvert møte et notat «Innspill til videre saksbehandling etter møtet med de etterlatte» som omhandlet fortsatte uklarheter i saken, om det burde innhentes mer informasjon, om nye tilsynsobjekter burde opprettes, forsøk på mulig konklusjon i saken og om det forelå vesentlig svikt $\mathrm{i}$ helsehjelpen. Prosjektleder gikk så ut av videre saksbehandling fordi det var et prosjekt og for å redusere risikoen for at prosjektleder påvirket sakens utfall. Andre leger hos fylkesmannen overtok de medisinske vurderinger senere og fullførte saken med saksbehandler.

Til sammen deltok hovedforskeren på åtte møter som observatør, noe som utgjør i overkant av 20 timer med observasjonsdata. Forskeren hadde i forkant av hvert møte fătt en kort innføring i hendelsen fra prosjektleder for å mentalt kunne forberede seg på møtet og saken som skulle observeres. Observasjonene innebar både tilstedeværelse på et kort formøte mellom prosjektleder og saksbehandler, selve møtet med de etterlatte, samt et kort oppsummeringsmøte mellom prosjektleder og saksbehandler i etterkant av møtet.

På møtene ble det benyttet en systematisk observasjonsguide (vedlegg II) for å strukturere observasjonene knyttet til både prosjektleder og saksbehandlers gjennomføring av møtene. Samme forsker deltok på alle møtene med de etterlatte for å sikre lik og systematisk bruk av observasjonsguiden. Notatene fra møtet ble i etterkant renskrevet av hovedforskeren selv og diskutert fortløpende med de andre forskerne som deltok i evalueringen. 
Tabell 2. Oversikt over deltagere i observasjon

\begin{tabular}{|c|c|c|c|}
\hline $\begin{array}{l}\text { Observasjon } \\
\text { av møte nr. }\end{array}$ & $\begin{array}{l}\text { Antall etterlatte og deres } \\
\text { relasjon til den avdøde }\end{array}$ & Kort beskrivelse av hendelsen & $\begin{array}{l}\text { Antall } \\
\text { saksbehandlere } \\
\text { til stede }\end{array}$ \\
\hline 1 & 1 (kone) & $\begin{array}{l}\text { Mann døde av hjerneblødning, historie med tiltagende } \\
\text { symptomer, mange aktører involvert. }\end{array}$ & 2 \\
\hline 2 & 2 (mor og far) & Ung kvinne død etter omfattende kreftkirurgi. & 2 \\
\hline 3 & 3 (mor, bror og søster) & $\begin{array}{l}\text { Mann døde av hjerteinfarkt, mulig sen respons fra } \\
\text { ambulansetjenesten. }\end{array}$ & 2 \\
\hline 4 & 2 (mor og datter) & $\begin{array}{l}\text { Mann funnet død på parkeringsplass. Uoppdaget } \\
\text { hjerteproblematikk ved nylig fastlegebes } \varnothing \mathrm{k} \text {. }\end{array}$ & 2 \\
\hline 5 & 2 (mor og far) & Barn døde i mors liv. & 2 \\
\hline 6 & 2 (mor og storebror) & $\begin{array}{l}\text { Ung mann begikk selvmord da han var innlagt på lukket } \\
\text { psykiatrisk avdeling. }\end{array}$ & 2 \\
\hline 7 & 1 (sønn) & $\begin{array}{l}\text { Ung kvinne som brukte blodfortynnende ble sendt hjem } \\
\text { etter konsultasjon, døde av hjerneblødning på } \\
\text { akuttmottaket. }\end{array}$ & 2 \\
\hline 8 & 3 (kone, sønn og datter) & $\begin{array}{l}\text { Mann døde av multiorgansvikt etter perforert } \\
\text { koronararterie under en akutt utblokking (PCI) grunnet } \\
\text { hjerteinfarkt. }\end{array}$ & 2 \\
\hline Totalt & 16 & & 16 \\
\hline
\end{tabular}

\section{Fokusgruppeintervjuer}

Fokusgruppeintervjuer med saksbehandlere fra fylkesmannen ble gjennomført i begynnelsen av prosjektet, seks måneder etter prosjektstart og 10 måneder etter prosjektstart, altså ved slutten av prosjektperioden til UiS.

Formålet med fokusgruppeintervjuene var å få innblikk i saksbehandlernes erfaringer med det aktuelle prosjektet. Bakgrunnen for å spre fokusgruppeintervjuene med involverte saksbehandlere over tid var å kunne samle informasjon om eventuelle endringer i deres synspunkter, opplevelser og vurderinger av involvering av etterlatte i selve tilsynssaken over tid. Saksbehandlere hadde i forkant av prosjektet variert erfaring med å kommunisere med etterlatte og pårørende utover per telefon i enkelte tilsynssaker. De ansatte hos fylkesmannen som deltok i prosjektet fikk derfor tilbud om en to timers forelesning med psykologspesialist angående ulike sorgstadier og sorgprosessen før prosjektet startet opp. Deltagerne på de ulike fokusgruppeintervjuene var i hovedsak de samme deltagerne, bare på tre ulike tidspunkt. Deltagerne besto utelukkende av saksbehandlere som deltok på møter med de etterlatte. Prosjektleder hos fylkesmannen ble etter drøfting ikke invitert til å delta i fokusgruppeintervjuene for å forhindre at deltagerne skulle føle seg forpliktet til å omtale møtene og sine erfaringer på en bestemt måte.

Det ble i alt foretatt tre fokusgruppeintervjuer. I fokusgruppeintervju nr.1 var det tre personer, i fokusgruppeintervju nr. 2 var det fem personer og i fokusgruppeintervju nr.3 var det fire 
personer. Hvert fokusgruppeintervju ble gjennomført med to forskere der hovedforsker hadde hovedansvaret for å stille spørsmål i tråd med utformet intervjuguide (Vedlegg III). Forsker nummer to hadde ansvaret for å stille eventuelle oppklarende spørsmål, samt å notere hovedmomenter fra innholdene $\mathrm{i}$ intervjuet og dynamikken i gruppen som deltok. Alle fokusgruppeintervjuene ble tatt opp på bånd og skrevet ut i sin helhet i etterkant.

\section{Analyse}

For å besvare forskningsspørsmålene er de individuelle intervjuene og fokusgruppeintervjuene tematisk analysert, inspirert av Braun og Clarke [15] sin fremgangsmåte. Observasjonsdataene er hovedsakelig brukt som supplerende materiale for å verifisere, avkrefte, støtte opp om identifiserte temaer og gi en dybde til forståelsen av møtet slik det foregikk i praksis.

\section{Analysesteg}

Datamaterialet fra fokusgruppeintervjuene og de individuelle intervjuene ble analysert separat, men tidsmessig parallelt. Dette innebærer at hvert analysemøte besto av to deler, en del hvor dataene knyttet til fokusgruppeintervjuene (saksbehandlerne) ble diskutert og en del hvor data knyttet til de individuelle intervjuene (etterlatte) ble diskutert. Observasjonsdataene ble brukt til å supplere data fra både fokusgruppeintervjuene og de individuelle intervjuene.

Det ble holdt analysemøter $\mathrm{i}$ to ulike faser for å skape konsensus angående formuleringer av tema. Den første fasen besto av tre ulike analysemøter mellom to av forskerne, hvor forslag til tema ble diskutert og utformet. I mellom analysemøtene ble det utformet beskrivelser av innholdet i de ulike temaene samt knytting av tema til passende sitater som kunne formidle innholdet. Fase to besto av i alt fire analysemøter hvor alle fire forskerne var involvert. Alle forskerne hadde på dette tidspunktet både lest intervjuene og observasjonsnotatene og foreløpige tema og beskrivelse av innhold. Det ble igjennom møtene diskutert og fastsatt tema, samt beskrivelse av innhold og bruk av sitater.

Rapporten og resultatene ble oversendt fylkesmannen ved prosjektleder for gjennomlesing og kommentarer, for å sikre at det ikke var misforståelser eller faktafeil i beskrivelsen. I etterkant av gjennomlesingen ble det gjort mindre justeringer.

\section{Forskningsetiske vurderinger}

All rekruttering av informanter til intervjuer med etterlatte, fokusgruppeintervju med saksbehandlere og organiseringen av møtene, der forsker var observatør, ble organisert og tilrettelagt av prosjektleder hos fylkesmannen. Alle deltagerne fikk informasjon om studiens formål og innhold både før og under datainnsamlingen. Alle deltagere signerte en 
samtykkeerklæring hvor de ble informert om at alle intervjudata ville bli anonymisert $\mathrm{i}$ videre bruk. De ble også informert om at de på et hvilket som helst tidspunkt hadde mulighet til å trekke seg i fra studien uten at det ville få noen konsekvenser. Det var ingen av deltagerne som på noe tidspunkt valgte å trekke seg fra studien. All datainnsamling ble gjennomført i fylkesmannens lokaler. Forskningsprosjektet er meldt og tilrådd av Norsk Senter for Forskningsdata (NSD) (ref.nr: 54865).

\section{Resultater}

Resultatene er kategorisert i de følgende fem ulike kategoriene: etterlattes opplevelse av møtet med fylkesmannen, etterlattes opplevelse av tilsynsprosessen, saksbehandlernes opplevelse av tilsynsprosessen, utilsiktede effekter rundt tiltaket og råd hvis innføring av møter i senere tilsynspraksis.

\section{Etterlattes opplevelser av møtet med fylkesmannen}

Her beskrives de etterlattes opplevelse av møtet. Intervjuene adresserte hele prosessen fra innkallingen til møtet og til tiden etter møtet. De etterlatte fremhevet følgende kategorier; Ønsket involvering og endring av praksis, bidra med ny informasjon, frustrasjon rundt helseinstitusjonene sin oppfølging, referatet; en ny kilde til utveksling av informasjon og gjennomføringen avgjørende for opplevelsen.

\section{Ønsket involvering og endring av praksis}

De etterlatte uttrykte generelt at de var positive til å bli innkalt til samtale med fylkesmannen og tatt med på råd. Mange av de etterlatte hadde igjennom sine tidligere møter med helsetjenesten hatt problemer med å bli hørt, noe som igjen hadde ført til at de følte seg maktesløse. Innkallelsen til møtet var derfor ofte en av de første anledningene hvor de etterlatte følte at deres erfaringer knyttet til hendelsen ble tatt på alvor. Det at fylkesmannen ønsket å få informasjon fra de etterlatte om hendelsen ble derfor opplevd som betryggende og at tilsynet var genuint opptatt av saken deres.

‘... for første gang så var det noen i øvrigheten, som jeg kaller det, som lyttet til det jeg hadde å si. For det er det aldri noen som har gjort. Ikke på den måten. [...] ... det gjorde så veldig mye godt for meg, da.' (Intervju 16).

De etterlatte uttrykte at det at de ble hørt i en så alvorlig sak burde være en selvfølge. De var overrasket over at ikke deres synspunkter og opplevelser knyttet til dødsfallet var en rutinemessig del av en tilsynssak. At de nå ble aktivt involvert i tilsynssaken opplevde de som mer rettferdig. 
Etterlatte som på eget initiativ hadde sendt inn en klage til fylkesmannen, opplevde innkallingen til møtet som en bekreftelse på at det var riktig å klage inn saken:

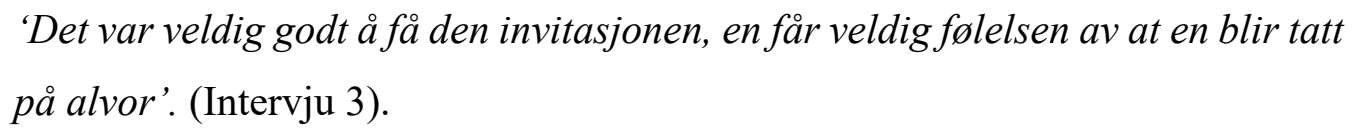

Observasjonsdataene understøttet disse funnene og viste i tillegg at både prosjektleder og saksbehandler brukte god tid på å muntlig informere om hva som var den overordnede hensikten med møtet og hva som var tilsynsmyndighetens mandat i en tilsynssak. Observasjonsdataene viste at både prosjektleder og saksbehandler la vekt på at fylkesmannen generelt sett hadde et systemperspektiv i den tilsynsmessige oppfølgingen av hendelsene. De forklarte i møtet at hensikten med tilsyn er hovedsakelig å forebygge fremtidige alvorlige hendelser, og ikke å sanksjonere enkelte helsepersonell i de ulike sakene. Observasjonsdataene viste liten eller ingen variasjon i selve gjennomføringen av møtene med de etterlatte.

Hovedmotivasjonen for deltakelse i et møte med fylkesmannen var de etterlattes ønske om at det hendelsesbaserte tilsynet av deres sak skulle kunne skape en endring av praksis i de ulike helseinstitusjonene. De etterlatte var opptatt av at ikke andre familier skulle måtte oppleve en alvorlig hendelse lik den de selv hadde opplevd. For de etterlatte representerte møtet en anledning til å åpent kommunisere opplevelser og videreformidle informasjon til fylkesmannen slik at de kunne være helt sikre på at tilsynsmyndighetene hadde all relevant informasjon som beslutningsgrunnlag forut for tilsynets konklusjon i deres tilsynssak.

'...det som har skjedd, det kan en ikke gjøre noe med, dessverre. Men en kan gjøre det en kan for at de samme feilene skal unngås med andre' (Intervju 6).

De etterlatte var i all hovedsak opptatt av at de nå hadde fått en anledning til å gi sin versjon av hendelsesforløpet. Flere av dem hadde slitt med tanker om at de hadde informasjon som burde bli hørt, og at det derfor var viktig at denne informasjonen kom frem:

'Jeg hadde ikke sittet igjen med en god følelse hvis vi bare hadde godtatt det. Vi har sagt fra og det letter i kroppen at vi har sagt fra nå da. (...) Da vi gikk ut derfra [fra møtet] var vi litt sånn lettet. Noe av presset på oss var borte liksom. At de undersøker saken, det er en god følelse opp i alt det vonde som har vart.' (Intervju 12). 


\section{Bidra med ny informasjon}

Det var enighet blant de etterlatte om at inkludering av de etterlatte i tilsynssaker er viktig for å få en grundig saksbehandling. De etterlatte var spesielt opptatt av at de sitter med avgjørende informasjon som er viktig for at fylkesmannen skal kunne vurdere saken.

Flere fortalte at de i møtet med fylkesmannen bidro med opplysninger som var nye for tilsynet og som førte til nye spørsmålsrunder mellom fylkesmannen og institusjonen involvert i tilsynssaken. Flere av de etterlatte mente at informasjon de bidro med i møtet med fylkesmannen bidro til å belyse hendelsesforløpet og derfor forbedret tilsynssaken:

\section{‘Jeg kan ikke få gjentatt hvor viktig det er at pårørende blir hørt! Så på bakgrunn av vårt møte [med prosjektleder og saksbehandler] så er det kommet inn nye opplysninger slik at det er sendt inn igjen til sykehuset som de da må svare tilbake på. Og det skjer ikke så veldig ofte’. (Intervju 17)}

Flere etterlatte uttrykte at det som var journalført i dokumentasjonen fra ulike helseinstitusjoner ikke var i samsvar med deres egen opplevelse av hendelsene. Ofte hadde de etterlatte vært tilstede selv, og hadde derfor et klart minne av hendelsen, men opplevde at journalnotatene ikke stemte med det som de mener faktisk skjedde. Det kunne være at viktige forhold var utelatt fra dokumentasjon og journalbeskrivelser, eller at beskrivelsene var direkte feil i forhold til hva de etterlatte hadde opplevd. Dette gjorde at de etterlatte følte et spesielt behov for selv å få møte fylkesmannen og fortelle sin versjon av hendelsesforløpet.

‘... så ... får man jo da ... deisende ned i postkassa en stor blekke med uttalelser fra alle. Det er jo på en måte opprørende og vondt å lese selvfølgelig ... og så er det mange detaljer der som ikke, jeg var jo tilstede ... som ikke jeg klarer å kjenne meg igjen i ... jeg hadde en helt annen opplevelse av det, da.' (Intervju 11).

Det ble spesielt trukket frem av de etterlatte at muntlig formidling opplevdes som mindre belastende enn å måtte skriftlig formidle sine innvendinger inn til fylkesmannen.

Observasjonsdataene bekreftet dette med å vise at informasjon gitt fra etterlatte til tilsynsmyndighetene i møtet kan hjelpe saksbehandler til å få et mer helhetlig bilde av hendelsesforløpet ved at de etterlatte bidro med utfyllende informasjon og førstehåndskunnskap om hva som hadde skjedd i den aktuelle saken. Dette gjaldt spesielt i langvarige og komplekse saker. 


\section{Frustrasjon rundt helseinstitusjonene sin oppfølging}

De etterlatte opplevde at helsetjenesten hadde hatt dårlige rutiner for å følge opp pårørende. En stor andel av de etterlatte hadde ikke blitt tilbudt noen form for samtale med helsepersonell i etterkant av dødsfallet. De hadde også inntrykk av at helsepersonell aktivt hadde forsøkt å skjule informasjon for dem og tilsynsmyndighetene, samt dekke over at det hadde skjedd feil knyttet til pasientbehandlingen. Mange etterlatte var frustrerte over helsepersonell eller et system som ikke var villige til å komme med noen innrømmelser og beklagelser:

‘... en må jo ha en vilje til å se på de tingene som skjedde. Og med henvisning til det pårørendemøtet [på sykehuset] som vi hadde, så ga [sykehuset] ingen signaler på det, ikke en halv mm engang, selv på ting som er åpenbare feil. Så det oppleves litt håpløst, det må jeg si. [...] ... så blir det heller et spørsmål om at de prøver å beskytte seg selv, og da sender en som ikke er villig til å innrømme noe'. (Intervju 6).

Flere av de etterlatte uttalte at dette ikke handlet om at de ønsket at noen skulle straffes, men at det viktigste for dem var at helsetjenesten kunne innrømme feil og lære av det:

'... det er ikke for å henge ut sykehuset eller noen som har gjort feil. Alle kan gjøre feil og sånn, men det er bare, legg det på bordet.' (Intervju 9).

\section{Referatet, en ny kilde til utveksling av informasjon}

De etterlatte som hadde mottatt referat fra møtet fremhevet at referatene gav en god oversikt over hovedpunktene som kom frem i møtet. Referatet i seg selv opplevdes som en bekreftelse på at den informasjonen de etterlatte hadde kommet med var blitt tatt på alvor. De etterlatte var også positive til at de hadde anledning til å sende inn kommentarer til referatet $\mathrm{i}$ etterkant av selve møtet.

'Vi har jo også fått referat fra møtet. Der har jeg kommet med noen innspill, det var en formell feil, men det har vi [de etterlatte] endret. Ellers synes jeg det var et godt referat. Et par punkter jeg vil legge til som er på grunn av vårt møte.' (Intervju 17)

En informant hadde med seg pasient- og brukerombudet på møtet, og opplevde at hun fikk hjelp av ombudet til å vurdere referatet mer formelt, og komme med tilbakemelding i etterkant til fylkesmannen, noe informanten opplevde som svært nyttig og som vedkommende anbefalte til andre. 


\section{Gjennomføringen avgjørende for opplevelsen}

Mange av de etterlatte var i forkant usikre på formålet med møtet. Flere hadde spekulert i om møtet representerte en mulighet for å få ny informasjon om selve tilsynssaken, og de lurte på hvem de skulle møte. Grunnet uavklart formål og innhold var flere både engstelige og bekymret ved oppmøtet. Til tross for dette sa alle de etterlatte at de opplevde møtet hos fylkesmannen som nyttig og godt av ulike grunner.

Først og fremst var de opptatt av at det var satt av nok tid til formålet. Det etterlatte fikk dermed god tid til å fortelle uavbrutt om hendelsesforløpet uten at de opplevde tidspress. De opplevde at prosjektleder og saksbehandler hadde satt seg godt inn i saken i forkant av møte, noe som bidro til økt tillitt til tilsynsmyndighetene. De etterlatte fremhevet også at det var rom for avklaringer, noe de mente var direkte knyttet til den muntlige formen på møtet. De etterlatte fremhevet at den muntlige formen opplevdes som mindre krevende og at det var lettere å oppklare misforståelser og nyansere informasjonen igjennom dialog. At det er forventet at man som etterlatt i sjokk og sorg etter et dødsfall skulle lese og skrive eventuelle tilsvar til tilsynsmyndighetene ble oppfattet som en ekstra stor belastning. Muligheten til å formidle opplevelser og informasjon direkte til tilsynsmyndighetene i et møte ble derfor fremhevet som ekstra viktig for de etterlatte. Det var også av avgjørende karakter at saksbehandler og prosjektleder klarte å skape en god ramme for møtet:

‘... jeg følte meg veldig komfortabel med de to personene. [...] Det var en fin atmosfcere og vi følte oss trygge.' (Intervju 2).

De etterlatte var også positivt overrasket over at det i møte ble fokusert på hvordan de som etterlatte nå hadde det. Tilsynssaken hadde for mange av dem vært svært inngripende $\mathrm{i}$ hverdagen og flere hadde opplevd det som belastende at de ikke følte de hadde gjort nok:

'Jeg har etter møtet sluttet å tenke at jeg ikke har klart å gjøre nok for moren min. Etter det møtet tenkte jeg at jeg har gjort det jeg kunne.' (Intervju 18).

Det å ha fått muligheten til å fortelle sin versjon av hendelsesforløpet bidro til en slags ro hos de etterlatte som var viktig. På tross av dette var det mange som sa at de ikke kunne føle seg helt fornøyd med møtet før de fikk vite utfallet av selve tilsynssaken.

\section{Etterlattes opplevelse av tilsynsprosessen}

De etterlatte opplevde det som krevende å forholde seg til tilsynsprosessen i sin helhet, både fordi det var vanskelig å sette seg inn i saksgangen i en tilsynsprosess og dens juridiske forhold, samtidig med at saken berørte dem sterkt følelsesmessig. 


\section{Sårbar situasjon}

Mange etterlatte var traumatiserte og slet med ettervirkninger av hendelsen slik som sjokk, sinne, sorg, konsentrasjonsproblemer, skyldfølelse og en generell mistillit til helsetjenesten.

'Det har vart en veldig tøff tid [er på gråten] ... en person som betydde enormt mye er ikke der mer. Kan aldri mer snakke med henne [...] Jeg er minst like satt ut nå som jeg var for et halvt år siden. Og jeg tror det kommer til å bli noen veldig tøffe måneder.' (Intervju 8).

I tillegg til sine egne reaksjoner og sårbarhet, måtte en del etterlatte dessuten ta seg av andre familiemedlemmer som var i sorg og krise. De etterlatte var derfor i utgangspunktet sårbare, noe som kunne gjøre det vanskeligere for dem å være mer aktivt deltagende i tilsynssaken. Dersom det var de selv som hadde klaget til fylkesmannen, kunne tilsynssaken oppleves spesielt belastende. Mange etterlatte gav uttrykk for at de følte seg små og maktesløse i møte med et mektig helsesystem:

\footnotetext{
‘Jeg tror det sitter ekstremt langt inne å klage på forholdene ved norske helseinstitusjoner, hvor du har dine pårørende, for du er redd for sanksjoner rett og slett.' (Intervju 4)
}

\section{Krevende prosess}

Flere etterlatte uttrykte at det ble mange dokumenter gjennom hele tilsynsprosessen å forholde seg til, og at det var vanskelig å holde oversikten. Dokumentene de fikk tilsendt minnet dem stadig på dødsfallet og hendelsene knyttet til det, noe som gjorde det enda mer krevende å forholde seg til dem. Når de etterlatte i tillegg opplevde uvilje fra helsetjenesten og helsepersonell i samarbeidet for å oppklare hendelsene rundt pasientens død, ble prosessen ekstra utfordrende. Følelser som maktesløshet kunne gjøre at de bare ønsket å bli ferdige med tilsynssaken for å slippe flere ubehageligheter.

Også møtene med fylkesmannen opplevdes som belastende, samtidig som informantene gav uttrykk for at de var glade for at de fikk tilbud om møtet og deltok.

'... det var en veldig tung dag (respondent 2 henviser til dagen de hadde møtet hos fylkesmannen), det var jo veldig emosjonelt, ikke sant, og så ... det var veldig tungt etterpå. Fryktelig vond dag, både dag og dagen etter. [...] ... det er opprivende, men det er jo samtidig en bearbeidelse av det å snakke om det, da. Så det er jo ... tvetydig egentlig, det er jo begge deler.' (Intervju 11). 
Mange av informantene påpekte hvilke ressurser de hadde som hadde hjulpet dem til å kunne delta i tilsynsprosessen. En informant hadde med seg pasientombudet, andre var selv utdannet advokater, en kjente fylkesmannen i et annet fylke som hun hadde snakket med om prosessen, andre var selv utdannet helsepersonell.

\section{'Jeg kjenner jo ganske godt til hvordan helsevesenet fungerer, hvordan det er organisert og kvalitetsarbeidet og fylkesmannens rolle, og det er klart at det hjelper jo med å skjønne hvilken prosess dette er'. (Intervju 3).}

Intervjuene tyder på at tilsynsprosessen og samtalen med fylkesmannen var utfordrende også for resurssterke informanter:

\section{'Jeg har jo vart saksbehandler $i$ staten $i$ mange, mange år, men jeg syntes allikevel at det var krevende å forholde meg til disse tingene.' (Intervju 4).}

Flere av de etterlatte påpekte at ikke alle har de samme ressursene som dem selv, og de mente at mange ikke ville være i stand til å aktivt delta i en tilsynsprosess. Mange gav uttrykk for ubehaget de opplevde ved å stå i en slags konflikt med helsetjenesten. Enkelte påpekte at de ikke sendte inn klagen selv, til tross for at de var klar over at helsetjenesten hadde sviktet $\mathrm{i}$ utførelsen av helsehjelpen. Intervjuene med de etterlatte tyder på at det å klage eller være involvert i en tilsynssak oppleves belastende:

$$
\begin{aligned}
& \text { 'Jeg var jo så redd for at selve motparten [representanter fra sykehjemmet] } \\
& \text { skulle vaere tilstede [i møtet], det hadde vart ubehagelig, siden det er en så } \\
& \text { alvorlig hendelse som endte med døden [skjelver i stemmen]' (Intervju 15). }
\end{aligned}
$$

\section{Saksbehandlernes opplevelser av tilsynsprosessen}

Her beskrives det hvordan saksbehandlerne opplevde å gjennomføre og delta i møter med etterlatte. Saksbehandlerne gav i stor grad uttrykk for positive erfaringer knyttet til å gjennomføre samtaler med de etterlatte og fremhevet spesielt kategoriene; økt kvalitet på tilsynsprosessen, skapte et helhetsbilde, bidro til gjensidig rolleforståelse.

\section{$\varnothing$ kt kvalitet på tilsynsprosessen}

I fokusgruppeintervjuene med saksbehandlerne som har deltatt i prosjektet, kom det frem at møter med etterlatte ofte kunne gi ny og verdifull informasjon om tilsynssaken, som saksbehandlerne mente at ikke ville kommet fram uten en samtale. Samtalene kunne føre til at fylkesmannen etterspurte mer informasjon fra helseinstitusjonen, eller at tilsynssaken ble utvidet til å omfatte flere instanser enn i den opprinnelige klagen. 
'Fikk en helt ny forståelse av saken [etter møtet med de etterlatte] og vi utvidet den og kommer til å utvide den til mange flere instanser ... [I] alle de sakene jeg har hatt så blir det flere runder med sykehusene etter samtalen. Fordi vi finner ut ‘å ja vi må spørre om det ', 'vi må spørre om det', 'vi må innhente det', og det ville vi vanligvis ikke gjort.' (Fokusgruppeintervju 1).

I noen tilfeller kom det frem informasjon i møtet som de etterlatte ikke var klar over at de kunne klage på, og derfor ikke hadde nevnt i sin skriftlige klage. For eksempel forhold som hadde å gjøre med hvilket tjenestenivå pasienten skulle behandles på. I andre saker hadde fylkesmannen fått informasjon om at enkelte helsepersonell hadde vært involvert $\mathrm{i}$ hendelsen, men der det ikke framkom av journalen at denne personen hadde vært involvert i det hele tatt:

'Vi hadde aldri greid a fange opp dette at de hadde vart involvert $i$ hendelsen overhodet. Så har vi fått informasjon fra pårørende ... så har vi da gått tilbake og det viser seg at her var det andre inne. Dette er helt klart informasjon vi ikke ville fått og som kan vare ganske alvorlig svikt, da.' (Fokusgruppeintervju 2).

Resultatene viste at den nye informasjonen de etterlatte bidro med kan ha betydning for utfallet av tilsynssaken. Mer informasjon om hendelsen, som utfylte den skriftlige informasjonen og gav saksbehandlerne en utvidet forståelse av hva som hadde skjedd. Dette kunne medføre at saken ble undersøkt videre, og fører til økt kvalitet på tilsynet:

'... det blir en økt kvalitet og vi går jo mye grundigere til verks $i$ de sakene enn vi ville gjort med ren skriftlig saksbehandling'. (Fokusgruppeintervju 1).

Saksbehandlerne opplevde dessuten at informasjonen de etterlatte kom med i møtet kunne være nyttig også for helseinstitusjonen involvert i tilsynet. Kanskje spesielt i saker som fylkesmannen hadde opprettet på bakgrunn av varsel fra Helsetilsynet:

'Vi har i flere tilfeller sendt referatet [fra møtet med de etterlatte] til sykehuset ... [...] ... de pårørende har ikke kommet med noen klager, derfor er ikke sykehuset klar over deres [de etterlattes] syn på saken i det hele tatt. Så jeg har tenkt at det derfor er veldig nyttig også for sykehuset å få vite hva de pårørende tenker.' (Fokusgruppeintervju 1).

Saksbehandlerne uttrykte at dette er nyttig informasjon for helsetjenesten når aktørene skal forsøke å forbedre tjenestene. Dessuten kan det ha stor betydning for det enkelte helsepersonell 
at hendelsesforløpet blir oppklart i størst mulig grad, blant annet med tanke på hvem som var involvert $\mathrm{i}$ hendelsen.

\section{Skapte et helhetsbilde}

Saksbehandlerne mente at et fysisk møte med etterlatte kunne være spesielt verdifullt $\mathrm{i}$ oppfølgingen av varselsaker fra Helsetilsynet, der pårørende ikke hadde klaget selv. Saksbehandlerne hadde da ikke noen informasjon i utgangspunktet om de pårørendes oppfatning av hendelsesforløpet i disse sakene.

'... vi har fått veldig mye verdifull informasjon [...] ... i de sakene [varselsaker fra Helsetilsynet] ville vi nok ikke hørt noe fra de pårørende sånn $i$ utgangspunktet, de ville kanskje kommet med et brev, men ikke i alle sakene.' (Fokusgruppeintervju 1).

I saker der det var mange instanser involvert, sa saksbehandlerne at møtet kunne være oppklarende for deres del, for å få et mer helhetlig bilde av hendelsesforløpet. Denne type saker ble opplevd som de mest nyttige sett fra et tilsynsperspektiv:

‘... hvis det er veldig mange instanser involvert så er det en ting å lese $i$ journaler, men som saksbehandler og ikke medisinsk kyndig, å få alt kronologisk, da. Det er veldig nyttig for videre saksbehandling også.' (Fokusgruppeintervju 1).

Generelt gav saksbehandlerne uttrykk for at da de hadde møter med de etterlatte, fikk de en større helhetsforståelse av hva som hadde skjedd med pasienten, og også en større forståelse av de pårørendes rolle i saken:

‘... typisk på sykehjem så har de [pårørende] sagt fra mange ganger, men det ble ikke gjort noe. [...] Det var ikke like tydelig [før vi begynte med møtene], fordi før så skrev de [pårørende] en klage kun på hendelsen og litt før. Men her [i møtene] får vi jo hele forløpet hvor de ofte har sagt at dette har skjedd før, jeg har meldt fra mange ganger og føler aldri det blir gjort noe. Det kommer mye mer frem [i møtene] at pårørende har vart på banen over lengre tid.' (Fokusgruppeintervju 2).

I møter med etterlatte som hadde klaget inn hendelsen til fylkesmannen på eget initiativ, opplevdes ikke alltid samtalen som like nyttig for saksbehandlerne. I noen tilfeller følte saksbehandlerne at de allerede i klagebrevet hadde forstått hva de pårørende ønsket å formidle 
i klagen sin, slik at møtet egentlig ikke gav noen ny informasjon, men heller føltes som unødig tidsbruk:

'... nå i det siste har jeg hatt flere saker som er opprettet på bakgrunn av klager, og der ... der ville jeg vel kanskje kunne sagt i utgangspunktet at vi ikke ville fått så veldig mye. Og det fikk vi heller ikke. Men at det heller var mer tidkrevende enn nyttig.' (Fokusgruppeintervju 3)

I andre saker hvor de etterlattes klage gjerne var vanskelig å forstå opplevdes møtet som oppklarende for saksbehandleren:

'Hvis det er klagebrev [fra de etterlatte] som er utgangspunktet så kan det voere noen som har skrivekløe, og du får ikke helt grep på ting. Men i en samtale så får du klarere for deg hvilke punkter som står sterkest hos dem [de etterlatte]. Hva de mener har gått galt.' (Fokusgruppeintervju 1).

Også der saksbehandlerne oppfattet den skriftlige klagen som ryddig og god, kunne møtet med de etterlatte være oppklarende, fordi man fikk ny informasjon, kunne stille spørsmål og fikk etablert en tydeligere tidslinje i saken. For de sakene som omhandlet rus og psykiatri, fremstod det som noe mer usikkert om møtene med etterlatte virket oppklarende på selve tilsynssaken:

'... jeg har erfart $i$ de selvmordsakene at det [møtet med de etterlatte] har egentlig ikke belyst det som har skjedd i helsetjenesten.' (Fokusgruppeintervju 1).

Samtidig tyder våre data på at møtet med de etterlatte kan være betydningsfullt også i saker som omhandler psykisk sykdom. Dette belyses best i resultatene rundt observasjonen av møtene og i intervju med etterlatte i disse spesifikke sakene som omhandler selvmord. Vi velger å illustrere dette med et sitat fra en etterlatt:

'Sykehuset skriver en redegjørelse til fylkesmannen der de skriver at sykehuset har fulgt alle prosedyrer og det fremstår som de har gjort alt riktig, men de har jo ikke kjent [avdøde]. De [sykehuset] har ikke vort interessert i å bli kjent med [avdøde]. Sykehuset har heller ikke ringt fastlegen hans slik vi ønsket fordi han kjente [avdøde] så godt. Det står $i$ alle informasjonsskriv at ved psykisk sykdom så må man ta pårørende med på laget og at det er så viktig ... men vi opplevde ikke det $i$ det hele tatt ...' (Intervju 17). 


\section{Bidro til gjensidig rolleforståelse}

Saksbehandlerne opplevde at møtet var viktig for de etterlatte ettersom det ofte er lettere å formulere seg muntlig enn skriftlig. Dette kunne både henge sammen med språkkunnskaper, den krevende situasjonen de etterlatte var i eller omstendigheter rundt klagen;

'Hun hadde brukt veldig mye tid på å skrive et brev til oss [...] ... fordi hun var så redd for å formulere seg feil. At noe skulle bli oppfattet galt fordi hun hadde kommet litt i klammeri med de i AMK. [...] Så det å kunne komme og fortelle muntlig er ofte lettere.' (Fokusgruppeintervju 2).

I tillegg til at saksbehandlerne mente at møtene hadde en betydning for de etterlattes følelsesmessige bearbeiding av hendelsen, mente de også at møtene kunne gi de etterlatte en bedre forståelse av saksgangen i tilsynssaker og fylkesmannens mandat, rolle og praktiske arbeid. Noe som igjen førte til at saksbehandlerne uttrykte at kvaliteten på arbeidet deres ble bedre.

Samtidig kunne saksbehandlerne i møtet bidra både med forklaringer og følelsesmessig støtte som kunne være til hjelp for de etterlatte og bety noe for deres videre bearbeiding av hendelsen. Når de etterlatte følte seg hørt og hadde hatt en positiv opplevelse av møtet, så gav det samtidig en positiv opplevelse for den saksbehandleren som var involvert:

'De [etterlatte i selvmordsaker] har alle sagt at det var godt å komme, så det var en veldig positiv opplevelse for meg. Ofte [...] ... er vi [fylkesmannens ansatte] vanskelig tilgjengelige, og nå satt vi der stille og hørte på, så det hadde en terapeutisk effekt da.' (Fokusgruppeintervju 1).

Saksbehandlerne gav uttrykk for at de hadde en viktig rolle i møtet overfor de etterlatte, selv om det var prosjektleder som ledet møtene. De opplevde at de selv uttalte seg ved behov i møtet, blant annet gjennom å etterspørre informasjon dersom de trengte det, og ved å møte de etterlattes følelser:

'Det er jo prosjektleder som har hovedrollen, men jeg spør der jeg trenger mer informasjon. Mellommenneskelig vil man jo utfylle hverandre. I møte med noen som kanskje gråter mye.' (Fokusgruppeintervju 2).

\section{Utilsiktede effekter rundt tiltaket}

Utilsiktede effekter omhandler ikke udelt negative opplevelser, men er heller en beskrivelse av konsekvenser i forbindelse med møtene. Utilsiktede effekter for de etterlatte handler om 
uklarhet $\mathrm{i}$ forventningen til møtet og varierende grad av tillit til fylkesmannen. Utilsiktede effekter for saksbehandlerne handler om økt tidsbruk, ny oppgave; krevende å møte etterlatte i sorg og krise og ønske om å møte flere 'typer' etterlatte.

\section{Etterlatte}

Uklarhet i forventningen til møtet

Noen etterlatte fortalte at de grudde seg til møtet med fylkesmannen. De var usikre på hvem de ville møte og noen var engstelige for at representanter for motparten (fra stedet det er rettet tilsynssak mot) ville være tilstede.

'... det kom jo et brev fra fungerende fylkeslege [...] ... men det sto ikke hvem som skulle komme, så jeg var litt usikker på, er det han vi skal møte eller er det ... hvem er det som skal møte på det kontoret. [...] ... man er redd for ... vil det vare noen andre som var tilstede $i$ hendelsen, da, sant. Det var mange sånne tanker [...] ... jeg $i$ hvert fall grua meg ... grua meg litt til det. Hvem er det man møter?' (Intervju 11).

For de etterlatte som ikke hadde sendt inn klage selv, og som ikke var klar over at det var opprettet en tilsynssak, kunne det oppleves som sjokkerende å motta møteinnkallelsen:

‘... å få det brevet i posten, det var liksom ... et sjokk. [...] ... jeg satt plutselig og tenkte, kanskje han kunne ha levd.' (Intervju 9).

Likevel var de glade for at saken ble undersøkt. Underveis i prosjektet endret fylkesmannen noe på ordlyden i innkallingsbrevet slik at det kom frem hvem de etterlatte ville møte. Majoriteten av de etterlatte gav uttrykk for at de kun delvis forstod fylkesmannens rolle som nøytral part i tilsynssaken, og sin egen rolle, som var å opplyse omkring hendelsesforløpet. Det var i enkelte tilfeller uklarhet rundt formålet med møtet, eller de etterlatte følte seg usikre på fylkesmannens hensikt med enkelte spørsmål eller hensikten med hele organiseringen av møtet. Noen etterlatte gav uttrykk for at de var usikre på om de fikk bidratt med det som var meningen, eller de stilte spørsmålstegn ved hvorfor de skulle fortelle så mye omkring hendelsesforløpet og hva fylkesmannen eventuelt ville få ut av informasjonen gitt i møtet.

'Det ble en litt kaotisk fremstilling fra min side ... [...] ... jeg satt igjen med det etterpå at hva var det vi egentlig var med på [ler]. Fikk de, jeg ble litt opptatt av, fikk de på en måte tak $i$ det de ville ha ut av oss?' (Intervju 14). 
Enkelte etterlatte var opptatt av at fylkesmannens agenda ikke egentlig samsvarte med de etterlattes agenda. En del tilsynssaker kunne fra de etterlattes ståsted, forstås som en konflikt mellom helseinstitusjonen/enkelte helsepersonell på den ene siden, og de etterlatte på den andre. De uttrykte at de opplevde at tilsynsmyndigheten da fungerte som en slags dommer som verken skulle støtte den ene eller andre siden, men innhente informasjon og foreta en uavhengig konklusjon basert på juridisk relevante fakta i saken. Noen informanter gav uttrykk for at de etterlatte burde være godt informert om fylkesmannens rolle for å være tilstrekkelig rustet til å delta i en tilsynsprosess, og for å vite hva de faktisk var med på da de kom:

'For man skal ikke tro at den samtalen med fylkesmannen er nøytral. De er part $i$ saken, på sett og vis, selv om de megler mellom to parter, og der kommer man som den ene parten ...' (Intervju 4)

En informant påpekte at de etterlatte kan ha behov for støtte og hjelp av en fagperson som er på de etterlattes og pårørendes side, dersom de selv ikke har tilstrekkelige kunnskaper til å vite hva slags informasjon de skal formidle til fylkesmannen og på hvilken måte.

\section{Varierende grad av tillit til fylkesmannen}

Intervjuene med de etterlatte viste at det var stor variasjon i tilliten til tilsynsmyndigheten. Enkelte etterlatte stilte spørsmålstegn ved fylkesmannens nøytralitet. De gav uttrykk for at de opplevde at fylkesmannen hadde en viss tilknytning til helsetjenesten, og ikke var en uavhengig instans som ville vurdere saken på et nøytralt grunnlag.

'... de kjenner mange av de som var involvert kanskje, enten det er helsepersonalet eller andre. De skal ha seg jobber senere, de skal ha referanser, folk snakker i miljøet osv, osv. Så det for fylkesmannen å vore helt uavhengig og tørre (ler) å ta oppgjør, sånn som det kanskje burde gjøres $i$ enkelte sammenhenger, det kan en stille spørsmålstegn ved. [...]' (Intervju 6).

Andre igjen gav uttrykk for en mistillit til hvor grundig eller etterrettelig fylkesmannen utfører sin tilsynsplikt:

'... tilsynsmyndighetene må vel ha en aktiv undersøkelsesplikt som går utover at det rettes en tilsynssak? De skal jo drive tilsyn. Hvor aktive er de? Jeg er nok litt spørrende til det altså.' (Intervju 4).

Generelt så ser det ut til at når de etterlatte innkalles til samtale og får møte de ansatte hos fylkesmannen ansikt til ansikt, så virket det tillitsskapende. Mange etterlatte uttrykte at de hadde 
tillit til fylkesmannens behandling av saken, og at når det er opprettet tilsynssak vil saken bli grundig undersøkt og eventuelle feil vil bli belyst.

\section{Saksbehandlerne}

De utilsiktede effektene for saksbehandlerne omhandlet i hovedsak økt tidsbruk, utfordringer knyttet til å treffe mennesker i sorg og krise og tanker rundt de etterlatte som ikke hadde svart på møteinnkallingen.

\section{$\varnothing k t$ tidsbruk}

Saksbehandlerne gav uttrykk for at de i forkant av prosjektet hadde fått informasjon om at møtet med etterlatte skulle kunne være tidsbesparende. Imidlertid var de tydelige på at saksbehandlingen tok mer tid dersom etterlatte skulle innkalles til møte:

'Vi har fått informasjon om at dette skal vare en del av at vi får informasjon tilgjengelig for oss, og at det skal voere mer effektivt på den måten, noe som jeg har skjønt kanskje ikke er helt tilfellet. Men dette tenker jeg er et tiltak for å øke kvaliteten og ikke effektiviteten. Fordi det tar litt mer tid med de sakene.' (Fokusgruppeintervju 1).

Saksbehandlerne opplevde at det var lite forståelse fra ledelsen eller myndighetene for at det tar mer tid å involvere de etterlatte i større grad, og at dette ikke samsvarer med offentlige anbefalinger. Høy kvalitet på saksbehandling av alle tilsynssaker var viktig for saksbehandlerne og i utgangspunktet var de positive til å innføre møter med etterlatte for bedre å kunne belyse hendelsesforløpet. Allikevel kom det klart frem at slik systemet nå er lagt opp samstemte ikke ressursene med tidsbruken:

'Det er kommet en NOU fra 'Arianson utvalget' som gir veldig klare signaler om økt brukerinvolvering og at det er noe som skal innføres $i$ større grad. På en eller annen måte skal vi få det til samtidig som vi blir nedbemannet.' (Fokusgruppeintervju 1).

Det ble allikevel pekt på viktigheten av at tilsynsmyndighetene i Norge oppfattes som åpne og transparente $\mathrm{i}$ alle sine prosesser og at en økt involvering av etterlatte i tilsynssaker som et slik møte representerer kan være en god måte å oppnå dette på. Men det er under forutsetning av at rammebetingelsene til saksbehandlerne endres i tråd med reell tidsbruk på saker der etterlatte skal innkalles til møte. 
Ny oppgave - krevende å møte etterlatte i sorg og krise

Å ha samtaler med etterlatte innebar å møte og høre på historiene til mennesker som var i stor sorg og hadde opplevd mye vondt. Dette var en ny oppgave for saksbehandlerne, som ellers var mest vant til skriftlig saksbehandling. Å møte sårbare etterlatte krevde noe annet og mer av fylkesmannens ansatte enn bare å undersøke om det hadde skjedd avvik i juridisk forstand. Det mellommenneskelige møtet med de etterlatte ble dessuten vanskeligere av at fylkesmannens representanter ikke kjente de pårørende fra før, annet enn fra journaldokumentene. Noen av saksbehandlerne hadde helsefaglig bakgrunn som for eksempel sykepleier eller psykolog fra tidligere. Disse saksbehandlerne uttalte at dette hadde vært en hjelp for dem i prosjektet, siden de hadde erfaring med å møte mennesker i sorg og krise. Andre saksbehandlere hadde aldri jobbet innen helserelaterte yrker tidligere, og da kunne det være en ekstra stor utfordring å gå inn i slike krevende møter:

'Det første møtet jeg hadde med et par som hadde mistet sin datter på 1,5 år var utrolig tøft. Jeg gruet meg veldig $i$ forkant og tenkte mye på det etterpå ...’ (Fokusgruppeintervju 1).

Den generelle opplevelsen fra saksbehandlernes side var imidlertid at det å møte etterlatte i sorg ikke har vært så vanskelig som de fryktet på forhånd:

'... så tenker jeg tilbake på det møtet vi hadde med henne så var hun utrolig fattet altså [i møtet] selv om hun sliter veldig $i$ etterkant. Møtene går overraskende bra.' (Fokusgruppeintervju 1).

I flere tilfeller opplevdes det som positivt for saksbehandlerne når de følte at møtet kunne være en bearbeidelse som var til hjelp for de etterlatte. Men saksbehandlerne fortalte også om blant annet etterlatte etter selvmord og etterlatte som hadde mistet et barm som slet med store selvbebreidelser. Flere av saksbehandlerne hadde dessuten opplevd etterlatte som var sinte. Saksbehandlerne hadde forståelse for hva de etterlatte slet med ut fra journaldokumentene innsendt i tilsynssaken, men da saksbehandlerne møtte etterlatte i møtet ble dette tydeligere. En saksbehandler uttrykte seg slik:

'... jeg har voert veldig imponert over de pårørende som er langt nede, selv er suicidale omtrent, og omtrent ikke har klart å møte opp, så er de rolige og saklige. På slutten av møtet spør [prosjektleder] om 'hvordan går det?' Da har vi sett noen som har forandra seg helt. Da har vi teoretisk sett visst at noen har 
det vanskelig, men da ser man plutselig at de har det veldig tøft.'

(Fokusgruppeintervju 2).

I møtet med de etterlatte opplevde saksbehandlerne at de selv ble følelsesmessig berørt, og de ønsket å møte de etterlatte som medmennesker. Rollen som medmenneske i en profesjonell sammenheng kunne være ny for mange av saksbehandlerne:

‘... jeg blir mer selvbevisst [i møtene]. Kroppsspråket, blikk og sånne ting. Jeg fokuserer på å virke sympatisk da. Sånn er man ikke foran dataen da [ler litt].' (Fokusgruppeintervju 2).

Samtidig med at saksbehandlerne ønsket å vise empati overfor de etterlatte i møtet, fortalte saksbehandlerne at de måtte være bevisste på sin rolle som tilsynsmyndighet, slik at de ikke gikk for langt i å foregripe en konklusjon eller gi løfter som vanskelig kunne innfris. Dette opplevdes utfordrende i et direkte møte med de etterlatte, fordi å møte mennesker i sorg og krise ansikt til ansikt, og høre deres historie, opplevdes mer moralsk forpliktende enn å forholde seg til skriftlige dokumenter. Balansegangen mellom å være empatisk og støttende, samtidig som man måtte være nøytral og ikke gi falske forhåpninger, ble beskrevet som en utfordring av flere saksbehandlere:

'Vi skal ikke vare et pasientombud eller sjelesørger, man skal passe på den rollen sin. [....] Så må man passe på å ikke foregripe noen konklusjon. [...] ... de [etterlatte] kan tenke at de [fylkesmannen] også syntes dette var veldig ille, men så viser det seg at vi vurderer det som greit. Ikke gi noen falske forventninger til konklusjonen.' (Fokusgruppeintervju 1).

I noen tilfeller opplevde saksbehandlerne at prosjektleder gikk for langt i å gi lovnader til de etterlatte, noe de opplevde som uheldig:

'Jeg har hatt litt problemer med at han [prosjektleder] konkluderer i møtene. Vi kan ikke komme med en konklusjon i saken før vi har fått inn dokumentasjon.' (Fokusgruppeintervju 2).

Våre observasjoner tyder på at den oppsummerende delen i slutten av møtet var en seanse der prosjektleder oppsummerte forløpet, forklarte spesifikke medisinske forhold og oppklarte eventuelle misforståelser. Det er trolig den delen av møtet som kan oppfattes som konkluderende av saksbehandlere. I flere tilfeller kunne saksbehandlerne være engstelige for at 
enkelte etterlatte gikk hjem med et inntrykk av at fylkesmannen var enig i deres synspunkter, og at de etterlatte dermed ville bli skuffet når de fikk se konklusjonen av tilsynssaken:

‘... så får vi også en god del informasjon [i møtene] som ... [...] jeg vet at vi ikke kommer til å ta tak $i$ i tilsynssaken, for jeg vet at de er mindre alvorlige, og de ikke er ... altså, tilstrekkelig til å kvalifisere til for eksempel brudd på forsvarlighet, da. [...] ... når man har hatt et møte med de, at vi kanskje skaper en forventning på at vi skal ta tak $i$ alle disse tingene også. Selv om vi tenker med en gang at dette kommer ikke til à bli tema.' (Fokusgruppeintervju 3).

Saksbehandlerne gav uttrykk for at det kunne oppleves som utfordrende etter et slikt møte å måtte avgrense tilsynssaken og utelate mange kritikkverdige aspekter som de etterlatte brukte mye tid på å snakke om i møtet. Spesielt fordi tilsynsmyndigheten selv hadde oppfordret de etterlatte til å fortelle om alt. Ofte hadde saksbehandlerne forståelse for de etterlattes synspunkter, og de kunne være enige $\mathrm{i}$ at forhold/hendelser hadde vært kritikkverdige, men dersom forholdene ikke falt inn under de oppgavene tilsynsmyndighetene var satt til å undersøke, ville det bli utelatt fra rapporten. De etterlatte i slike saker kan ha gitt uttrykk for at de er fornøyde med møtet, men saksbehandlerne var usikre på hvordan de etterlatte ville reagere etter konklusjonen av tilsynet, som de antok ikke vil være i tråd med hva de etterlatte hadde ønsket eller forventet.

Saksbehandlerne gav uttrykk for at møtet med fylkesmannen kunne gi etterlatte en økt innsikt i og forståelse av tilsynsmyndighetens rolle. Enkelte saksbehandlere gav uttrykk for at møtet var en mulighet for økt gjensidig rolleforståelse. Det at de etterlattes synspunkter ble kommunisert til saksbehandlerne kunne føre til at de etterlatte lettere kunne akseptere fylkesmannens konklusjon i tilsynssaken, selv om tilsynsmyndigheten ikke hadde konkludert med pliktbrudd i saken:

'Jeg har opplevd tidligere hvor vi har møtt disse som klager, før prosjektet, der det egentlig heller er det motsatte av det du tenker [at de pårørende vil bli misfornøyd dersom fylkesmannen ikke konkluderer med pliktbrudd]. At de på møtet får en forståelse av at 'alt jeg sier er blitt hørt' og at de har forstått vår konklusjon likevel, selv om vi er kommet til at det ikke er pliktbrudd.' (Fokusgruppeintervju 2). 


\section{Ønsket å møte flere 'typer' etterlatte}

Saksbehandlerne fortalte at det forekom at etterlatte ikke svarte på møteinvitasjonen fra fylkesmannen. De spekulerte over årsaken til at etterlatte ikke svarte, blant annet om det kunne ha med bakgrunnen deres å gjøre (uvante med akademisk språk for eksempel), mistillit, eller mye frustrasjon og vanskelige følelser:

'De som vi ser er sintest på sykehuset, det ser jeg ut ifra journalen, og kanskje litt mer sånn akademiker fjerne eller ikke så skrivesterke som jeg synes det kunne vart fint å møte, de har ikke sagt ja [til samtale med fylkesmannen]. (Fokusgruppeintervju 1).

Saksbehandlerne gav uttrykk for at de ønsket å møte etterlatte som de følte hadde behov for det, og syntes det var synd dersom disse ikke møtte opp:

'De [etterlatte] mistet sønnen og skrev en veldig lang klage, men også 'vi ønsker å møte fylkesmannen for å kunne forklare dette', skrev de. Så tok vi dem inn $i$ prosjektet, men så hører vi ingenting ... [...] Det synes jeg er synd.' (Fokusgruppeintervju 1)

Noen av saksbehandlerne gav uttrykk for at de oppfattet at det var en fare for manglende likebehandling i tilsynssaker, dersom det var de etterlatte med mest ressurser (høy utdannelse, lønn) som takket ja til møteinvitasjonen:

'Noen [etterlatte] hadde med seg pasientombud til samtalen. De hadde satt seg veldig inn $i$ alt på forhånd, hadde med seg papirer, skrevet hendelsesforløpet. Det er veldig oppegående mennesker, altså. Men hvor blir det av disse som ikke er fullt så oppegående, da?' (Fokusgruppeintervju 1).

Saksbehandlerne uttrykte at de hadde et ønske om å utjevne disse forskjellene, men var usikre på om innføring av møter med etterlatte ville bidra til dette. Saksbehandlerne undret seg over om både usikkerhet rundt fylkesmannens rolle og det juridiske språket i møteinnkallingen kunne oppfattes som fremmed for enkelte etterlatte og at de etterlatte derfor ikke ønsket å delta på møtet. 


\section{Råd hvis innføring av møter med etterlatte}

\section{Råd fra de etterlatte}

En del av de etterlatte savnet mer og bedre informasjon i forkant av møtet hos fylkesmannen.

De ønsket seg bl.a. skriftlig informasjon om hensikten med møtet, og om hvem som skulle delta og ønsket noe mer informasjon om saksgangen i tilsynsprosessen. En av de etterlatte var ikke klar over at det kunne ha skjedd et avvik på sykehuset før hun mottok brevet fra fylkesmannen. Vedkommende uttrykte at hun ønsket å få informasjonen om dette på en annen måte:

'Så jeg mener at man kanskje skulle ta en telefon på forhånd og si ... (...) ... at man ved plutselig dødsfall undersøker saken. (...). Sånn at man, når det brevet kommer [fra fylkesmannen], er litt forberedt' (Intervju 9).

Videre hadde de etterlatte synspunkter på når i prosessen det er hensiktsmessig å invitere etterlatte til et møte. De etterlatte sa for eksempel at det var positivt at møtet kommer en stund etter dødsfallet, slik at de hadde fått det hele litt mer på avstand før de skulle treffe fylkesmannen. Samtidig ønsket de ikke å vente alt for lenge (innen 6-12 måneder etter dødsfallet), slik at hendelsene fortsatt lå friskt i minnet. De var også opptatt av at de, etter å ha mottatt brevet, ville slippe å gå og vente på at møtet skulle finne sted:

'... hvis de [fylkesmannen] sender ut det brevet, så gi dem [de etterlatte] gjerne ti dager, å tenke over dette her. Men så ikke lengre. For at man må få lov å bli ferdig med det. [...] ... man går jo hele tiden og får ikke ro [mens man venter på møtet], ikke sant?’'(Intervju 9).

Informanten som hadde med seg pasient- og brukerombudet, mente at fylkesmannen burde anbefale de etterlatte å ha med seg ombudet og dessuten formidle relevante kontaktopplysninger til de etterlatte i forkant av møtet. Noen etterlatte foreslo at fylkesmannen sendte ut noen spørsmål i innkallingen, som kunne være en hjelp for de pårørende til å forberede seg.

\section{Sentrale personlige egenskaper og kompetanse hos fylkesmannens ansatte}

De etterlatte opplevde generelt at de ble møtt på en god måte av de ansatte hos fylkesmannen. Både intervjuene med de etterlatte, fokusgruppeintervjuene og observasjonsnotatene tyder på at kompetansen til ansatte hos fylkesmannen som gjennomførte møtene var avgjørende for kvaliteten på samtalen. Det var nødvendig å ha med en person med medisinskfaglig utdanning og erfaring, som i tillegg hadde erfaring med og kompetanse til å gjennomføre vanskelige samtaler med mennesker i dyp sorg. 
'Prosjektleder er veldig flink til å kjøre møtene og det er betryggende for meg som saksbehandler [...]. Han er trygg i rollen ...' (Fokusgruppeintervju 2).

De etterlatte uttrykte at det var viktig at personene som gjennomførte møtene kunne tilpasse seg de etterlattes behov i gjennomføringen i form av å kunne vise empati og interesse gjennom det som blir kommunisert, i både kroppsspråk og tonefall:

'At man føler at man blir sett og føler at man har den empatien, det, jeg tror det er veldig viktig $i$ sånne møter. [...] ... man er så sårbar, man er innmari sårbar. Man kjenner på stemningen, man ser på personene hvis man er uinteressert eller litt sånn ...ja. Så kan det bli veldig feil. Vi opplevde det jo ikke sånn i det hele tatt, vi opplevde det veldig sånn empatisk og ... og hadde veldig forståelse og ... [prosjektleder og saksbehandler] synes det var flott og tøft at vi kom, og, ja. Det er liksom sånne små ting, da. Som, at man kan si det at 'ja, det er flott at dere møter, vi er jo utrolig takknemlige for det'. Det er sånne, det ... det er liksom sånn, litt sånn ... ja, overflatisk, men allikevel veldig viktig.' (Intervju 11).

Vektleggingen og viktigheten av prosjektleders og saksbehandlers evne til å skape trygghet og vise empati i møte med de etterlatte gikk igjen i flere av intervjuene med de etterlatte. Evnen til å vise empati gjennom hva som ble formidlet og gjennom kroppsspråk blir trukket frem som en viktig forutsetning for at man som etterlatt skulle klare å formidle informasjon rundt hendelsesforløpet. Det at prosjektleder i slutten av møtet direkte spurte de etterlatte om hvordan det gikk med dem nå, om de var i jobb, hvordan de hadde det opplevdes som viktig og en av de etterlatte uttalte det slik:

'Det han også (prosjektleder) sa i møtet som jeg har bitt meg merke $i$ var at han sier «hvordan går det med dere?»...hva gjør dere for ikke å gå til grunne. Prosjektleder sier at han har opplevd at familier har gått til grunne. Og det er sånn at når man sitter der og hører utenfra at det er viktig å ta vare på seg selv og det er godt å høre fra en utenforstående. Ta vare på dere selv...stå sammen....det var en liten trøst at de bryr seg om oss...en som sitter hos fylkesmannen og er en erfaren person som har sett mange saker...at han har sett mange familier som har gått til grunne ....' (Intervju 17).

Intervjuene med etterlatte pekte på betydningen av at prosjektleder og saksbehandler hadde et ønske om å treffe de etterlatte. Våre data tyder på at prosjektleder var en viktig person for gjennomføringen av møter med etterlatte: 
'[Prosjektleder] har jo som sagt vart en stor pådriver for dette her [å møte de etterlatte]. [...] Vi hadde jo samtaler før han begynte også, men det var mye sjeldnere.' (Fokusgruppeintervju 1).

I fokusgruppeintervjuene gav saksbehandlerne uttrykk for at prosjektleders medisinskfaglige bakgrunn var nødvendig for god kvalitet på møtene, fordi prosjektleder kunne forklare medisinske vurderinger og svare på spørsmål fra de etterlatte. Imidlertid var saksbehandlerne tydelige på at man ikke må gå for langt i å forklare eller indikere noe om utfallet av tilsynssaken i møtet. I de sakene som omhandlet kommunehelsetjenesten, mente saksbehandlerne at det ideelle fra deres synspunkt ville vært om en lege i kommunehelsetjenesten var møteleder i saker som omhandlet kommunehelsetjenesten, også fordi det var denne legen som ville ha ansvar for saken videre etter møtet.

Observasjonsnotatene viste at de ansatte hos fylkesmannen hadde brukt mye tid på å sette seg grundig inn i sakene før møtet med de etterlatte. Enkelte etterlatte uttrykte likevel at de ikke opplevde at fylkesmannen hadde satt seg godt nok inn i saken deres.

'... det hadde vart et enda mye bedre møte hvis de hadde hatt mulighet til à forberede seg på forhånd på de tingene som vi hadde skriftlig levert. [...] ... hvis fylkesmannen hadde voert godt forberedt, så hadde han sett at det mangla en del i journalen.' (Intervju 6).

\section{Hvordan ivareta etterlatte som er involvert i en tilsynssak?}

Med tanke på den store belastningen det var for de etterlatte å delta i en tilsynssak, synes det å være et viktig spørsmål hvordan man på best mulig måte kunne ivareta de etterlatte både i selve møtet men også i etterkant. Ett råd fra de etterlatte var at fylkesmannen må ha oppmerksomhet på ettervern av de pårørende etter en slik samtale, og ha konkrete forslag til hvordan de som trenger det kan få hjelp. Konkret kunne dette bety at fylkesmannen hadde forslag til oppfølgingstiltak som de kunne tilby etterlatte som hadde behov for det. Våre funn i evalueringen tyder ikke på at møtet bidrog til å gjøre de etterlattes situasjon vanskeligere i form av for eksempel å forsterke krisen de var i.

\section{Etter møtet}

Pårørende savnet mer informasjon om hele saksgangen i tilsynsprosessen og rådet fylkesmannen til å informere om en omtrentlig tidslinje for videre aktiviteter i saken.

'... jeg føler at det kunne vort fint å hatt en slags tidsplan, 'hva skjer videre nå'. Når hører vi fra dere igjen, hva skal skje?' (Intervju 8). 
Et annet råd var et nytt møte mellom de etterlatte og fylkesmannen mot slutten av tilsynssaken. Et slikt møte ville kunne gi de etterlatte større innflytelse, ved at de da kunne uttale seg på ny når konklusjonen nærmet seg, og oppklare eventuelle misforståelser som de regnet med kunne foreligge etter at fylkesmannen hadde innhentet dokumentasjon i saken.

\section{Diskusjon}

Brukerinvolvering i tilsyn er et strategisk satsningsområde omtalt i Strategisk plan for Statens helsetilsyn 2015-2019. Planen beskriver eksplisitt at Helsetilsynet skal ha som mål at brukere skal være involverte i alle tilsynsaktiviteter. Resultatene av evalueringen av prosjektet 'De etterlatte ved hendelsesbaserte tilsyn av dødsfall' viser på den ene siden at denne spesifikke metoden kan være et nyttig bidrag til at dette målet kan oppnås. På den andre siden viser funnene at det er ulike hensyn og vurderinger som må tas i betraktning for å lykkes med en slik type brukerinvolvering. Hovedpunktene bak denne argumentasjonen vil bli presentert i den videre diskusjonen. Prosjektet 'De etterlatte ved hendelsesbasert tilsyn av dødsfall' vil heretter omtales som 'det aktuelle prosjektet'

\section{Riktig med $\varnothing$ kt brukerinvolvering}

Drivkreftene for å øke bruken av brukerinvolvering i tilsynspraksis er sterke både nasjonalt og internasjonalt $[6,7,24]$. På tross av dette finnes det lite litteratur om hvordan en rent praktisk kan innføre og operasjonalisere involvering av brukere i tilsyn [13]. Dette kan igjen være bakgrunnen for at det tilsynelatende er liten involvering av etterlatte i tilsynspraksis. For å kunne øke graden av brukerinvolvering i norsk tilsynspraksis er det derfor behov for utvikling og beskrivelser av gode metoder for å involvere brukerne i tilsyn, noe denne rapporten representerer. For å øke brukerinvolvering er det også viktig at bakgrunnen for involveringen er kunnskapsbasert og godt forankret i organisasjonen. Dette er i tråd med funnene Lippestad [5] presenterer i følgeevalueringen av den overordnede satsingen fra Helsetilsynet.

Både de etterlatte og saksbehandlerne bekrefter at de opplevde brukerinvolveringen som både et riktig steg i forhold til politiske føringer, men også at det føltes mer rettferdig at de etterlatte fikk en mulighet til å uttale seg i saken. Dette samsvarer med Kok m.fl. [16] sin studie fra Nederland, som peker på at rasjonale for økt brukerinvolvering $\mathrm{i}$ analyser av alvorlige hendelser, i hovedsak følger to argumentasjonslinjer: 1) et moralsk rasjonale for å involvere etterlatte og pårørende sett ut ifra et etisk prinsipp og 2) en epistemologisk rettferdiggjøring $\mathrm{i}$ form av at det er de etterlatte selv som er ekspertene på sine egne subjektive erfaringer knyttet til dødsfallet av et familiemedlem og på denne måten kan informere tilsynssaken og 
tilsynsmyndighetene ved å fortelle om sine opplevelser knyttet til hendelsen. Følger vi Kok m.fl. [16] sin argumentasjon, bør de etterlattes erfaringer og perspektiver sees på som verdifulle i tilsynsaktiviteter og representere kjerneinformasjonen i enhver tilsynssak, noe som også har likhetstrekk med funn i denne evalueringen.

I tillegg symboliserer tilsynsmyndighetene med et slikt møte at informasjonen fra de etterlatte vektlegges som viktig informasjon til fylkesmannen i gjennomgang av den enkelte saken. Muligheten til en mer direkte og åpen kommunikasjon har også bidratt til økt tillitt mellom partene, samt bedre gjensidig forståelse av roller og tilsynets oppgave. Det kan også argumenteres for at innretningen av tilsynsaktiviteten der de etterlattes erfaringer inkorporeres på linje med elementer knyttet til klinisk effektivitet (riktig behandling) og pasientsikkerhet går i retning av å være i tråd med Doyle, Lennox [17] som hevder at disse tre kvalitetsdimensjonene må ses i sammenheng.

\section{Endret praksis krever endring i ressurser}

Innføring av et møte med etterlatte er en endring som fører med seg relativt store omveltninger i praksis i de aktuelle sakene. Det har tidligere i tilsynssammenheng ved det studerte fylkesmannsembetet vært liten eller ingen tradisjon for å invitere etterlatte og pårørende til noen form for møte eller samtale for å innhente informasjon om dødsfallet og å se hendelsen ifra fra de etterlattes ståsted og opplevelse. Endringen i seg selv er viktig og i tråd med Helsetilsynet [8] sin strategiske satsning på involvering ettersom det er et skifte fra at en ikke bare er opptatt av hvorfor tilsyn føres men også til å omhandle hvordan tilsyn føres.

Endringen av form for involvering stiller dermed også endrede krav til saksbehandlingen. Dette gjelder både i form av opplæring og kompetanse hos saksbehandlerne som skal møte mennesker som potensielt sett er i en krise, samt til den disponible tidsbruken i disse sakene. Funnene fra evalueringen viser klart at saksbehandlerne opplevde at tidsbruken økte både fordi møtet krevde tid og forberedelser, men også ettersom tilsynssakene ofte ble utvidet. Tilsynssaken ble utvidet med flere aktører, innhenting av ny informasjon, som igjen kunne medføre at involverte aktører skulle uttale seg. Basert på data samlet i evalueringen, er det ikke mulig å sjekke om saksbehandlingstiden gikk ned i noen av sakene, for eksempel ved at sakene ble lukket raskere basert på informasjon fra etterlatte. Dette vil belyses i en senere evaluering hos fylkesmannen av det samlede utvalget for alle 50 sakene (endret saksflyt og fullstendig bilde av tidsbruk $\mathrm{i}$ saksbehandlingen). 
Tidsbruken var også en helt tydelig faktor hos de etterlatte hvor nettopp det at de fikk tid til å forklare sin side av saken, ble høyt verdsatt. Funnene viser også at saksbehandlernes sosiale, profesjonelle og medmenneskelige egenskaper var avgjørende for den positive opplevelsen til de etterlatte. En potensiell innføring av en slik praksis som det aktuelle prosjektet representerer fordrer dermed at det blir satt av ressurser til å følge opp det endringen av praksis innebærer i form av tid, opplæring og ressurser.

\section{Involveringen kan gi økt kvalitet på tilsynet}

Møtet i det aktuelle prosjektet bidrog til økt grad av informasjon for å belyse tilsynssaken. De etterlatte kunne komme med ytterligere utdypning av eksisterende informasjon, avkrefte informasjon og komme med helt ny informasjon i møtet, som igjen medførte ytterligere informasjonsinnhenting fra involverte helseinstitusjoner. Noen ganger ble også feiloppfatninger korrigert. Dette var også noe av grunnen til at de etterlatte opplevde at det var så betydningsfullt å bidra i tilsynssaken, til tross for den store emosjonelle påkjenningen det kunne være. Tidligere forskning har vist at tilsynsmyndigheter i større grad kan nyttiggjøre seg av en mer direkte dialog med involverte parter når man skal innhente informasjon i saker [18, 19]. Dette kan dreie seg om intervjuer eller møter med involverte parter i motsetning til kunnskapsinnhenting som i hovedsak baserer seg på gjennomgang av journalnotater, dokumenter og skriftlige uttalelser. Slike møter med involverte parter kan bidra til mer effektive læringsprosesser og bør i større grad utforskes med tanke på videre metodeutvikling i konteksten av tilsynsmyndighetens mandat og aktiviteter $[18,19]$. Sentralt for å få dette realisert er en sterk ledelsesforankring og videre utvikling av seleksjonskriterier knyttet til hvilke type saker som egner seg for en mer direkte dialog med involverte parter i de ulike tilsynssakene.

Frem til nå har det vært manglende kunnskap om hva etterlatte sin involvering i tilsyn kan bidra til, og tiltaket dette prosjektet representerer er i så måte innovativ [7, 20]. Innovasjon i tilsynsmetoder for å innhente et godt kunnskapsgrunnlag for vurdering av tilsynssaker er $\mathrm{i}$ stadig utvikling, og $\mathrm{i}$ den senere tid har brukerinvolvering stått sentralt nasjonalt og internasjonalt $[11,12,24]$. Funnene i studien viser at de etterlatte ofte hadde en oppfatning av hendelsesforløpet som var ulik det som var kommunisert i den skriftlige kommunikasjonen tilsynet tidligere hadde innhentet. Noe som også er resultatene i tilsvarende studier [3, 16, 21] der forskerne finner at pasienter og etterlatte vektlegger andre elementer knyttet til alvorlige hendelser enn det helsepersonell og saksbehandlere gjør. Studiene peker også på at det er en maktubalanse i disse relasjonene som kan virke inn på hvilken informasjon som kommer frem og etterspørres. 
På den ene siden viste resultatene at de etterlatte i flere tilfeller hadde en opplevelse av at de bidro med ny og nyttig informasjon, noe funnene fra saksbehandlerne også understøtter. På den andre siden er det fremdeles slik at tilsynsmyndighetene sitter med beslutningsmyndigheten til å bestemme hvilken informasjon som er 'viktigst'. Dette vil si at det kan være at informasjon som de etterlatte anser som essensiell, ikke blir tatt med i betraktning ettersom tilsynsmyndighetene ikke anser det som aktuelt for å beslutte om det foreligger kritikkverdige forhold i juridisk forstand. Hvem sin informasjon som skal vektlegges, og hva som skal anses som viktig informasjon i en slik sak bør derfor være gjenstand for ytterligere diskusjon og videre forskning. Innen litteraturen relateres dette til «epistemic injustice» [22] som det trolig er relevant for både videre forskning og tilsynspraksis å gå nærmere inn i for å få en forståelse av hvordan informasjon velges ut i saker og om det er behov for å gjøre endringer.

Det er viktig å påpeke at på tidspunktet datainnsamling fant sted, hadde ikke fylkesmannen kommet frem til en konklusjon i de ulike sakene som var med i utvalget. Dette kan ha påvirkning på funnene som kommer frem i evalueringen både fra saksbehandlerne og fra de etterlatte. Dette var et bevisst metodisk valg som ble gjort for å få et riktig bilde av tiltaket uten at det skulle være farget av hvilket utfall saken fikk. Det er heller ikke sett nærmere på om bidragene til de etterlatte har vært utslagsgivende for konklusjonen av tilsynssaken, noe som kunne ha vært interessant i seg selv. Likevel viser studien at resultatene kan forstås i tråd med Kok m.fl. [16] som peker på at den moralske siden av involveringen i seg selv kan være så viktig at konsekvensene det har for utfallet blir sekundært.

Involvering av etterlatte har også bidratt til å gjenopprette tillit til tilsynet og dets arbeidsmetoder og til å øke graden av innsyn som brukerne har i måten fylkesmannen utfører sine arbeidsoppgaver på. Gjennom prosjektet hos fylkesmannen endret man arbeidsmetoden og det ble generert nye opplysninger knyttet til de enkelte tilsynssakene og på denne måten kan man lære mer om årsakene som førte til svikt og oppnå læring på systemnivå. Funnene viser at det er saksbehandleres opplevelse at kvaliteten på tilsynet blir bedre ettersom dette møtet gir dem en helt ny mulighet til å skaffe seg et oversiktsbilde over hendelsen, samt utvide tilsynet på bakgrunn av ny informasjon fra de etterlatte. Prosjektet har dermed potensiale for å være en god metode for å øke brukerinvolveringen i disse alvorlige og krevende tilsynssakene. Det at fylkesmannens saksbehandlere fremstår som åpne og transparente i saksbehandlingen, åpner for tettere dialog og kommunikasjon og viser en genuin interesse for etterlattes perspektiv $\mathrm{i}$ saken, kan styrke de etterlattes og pårørendes rolle i slike alvorlige og ofte komplekse tilsynssaker. Hvordan tilsynsmyndigheter skal innhente de etterlattes kunnskaper og 
perspektiver og hvordan de skal involveres i hendelsesbaserte tilsyn av dødsfall på best mulig måte, er noe som bør være gjenstand for videre utprøving og innovasjon i en større skala enn det aktuelle prosjektet vi har evaluert [16].

Behovet for likebehandling i saksbehandling og muligheter for å differensiere metodebruk i ulike saker, var et området som saksbehandlerne diskuterte. Det å etablere metoder der man antar at ressurssterke etterlatte vil delta, mens mer antatt ressurssvake ikke møter for å presentere sitt perspektiv, kan være en utfordring for fylkesmannen. Samtidig, kan en ikke nødvendigvis bruke det som et argument for å ikke involvere etterlatte i det hele tatt. Det bør jobbes videre med kriterier for utvelgelse av saker slik at man kan styrke involvering av etterlatte på måter som både bidrar til tilsynsmessig opplysning av saken, men også til at etterlatte som ønsker å bli involvert, får mulighet til det.

\section{Mulige begrensninger}

Studien har noen mulige svakheter som vi ønsker å bemerke. Først og fremst kan utvalget av etterlatte som ble invitert i møte med fylkesmannen ha skjevheter. Det var bekymring hos saksbehandlerne om at det var de mest ressurssterke som takket ja til å delta i møtet. Dette kan derfor også prege utvalget som takket ja til å delta i evalueringen som SHARE gjennomførte, fordi det innebar å delta i intervju med forsker i tillegg til å delta på møte med fylkesmannen.

Evalueringen til SHARE har ikke benyttet seg av data som fylkesmannen samlet inn fra etterlatte i spørreskjema som ble distribuert. Dette var ikke en del av oppdraget i evalueringen. Vi er av den oppfatning at resultatene fra SHARE sine observasjoner, individuelle intervju med etterlatte og fokusgruppeintervju med saksbehandlere bør ses i sammenheng med fylkesmannens egne data for å få en enda mer utfyllende evaluering av hele prosjektet. Herunder bør det gås mer inn i tidsbruk og avslutning av saker. Likevel, vil vi bemerke at datagrunnlaget til SHARE sin evaluering var sterkt for å kunne svare på vårt oppdrag.

\section{Konklusjon}

Det å invitere etterlatte til et møte med fylkesmannen er både et viktig signal og innovativt metodisk i form av at det beskriver en potensiell måte å øke brukerinvolveringen i tilsyn på. Funnene fra evalueringen viser at de etterlatte anser det som både viktig og rettferdig at de involveres til tross for at det kan være en følelsesmessig påkjenning. Evalueringen har også vist at fylkesmannen i møte med etterlatte og pårørende har fătt til dels ny og utfyllende informasjon om hendelsen som i enkelte saker har ført til innhenting av ytterligere dokumentasjon og redegjørelser fra involverte helseinstitusjoner. Tiltaket kan i seg selv dermed bidra til økt 
kvalitet på tilsynsaktiviteter ettersom det både gir et mer helhetlig bilde av hendelsene og at involveringen i seg selv anses som viktig ut i fra et moralsk og etisk prinsipp. Samtidig er det viktig å understreke at innføring av en slik slikt type involveringstiltak fordrer at det fører med seg de nødvendige ressursene i form av tid og opplæring som trengs for at tiltaket skal kunne gjennomføres på en meningsfull måte for både tilsynet og de etterlatte.

\section{Implikasjoner for praksis}

Basert på funnene beskrevet i denne rapporten er det naturlig å foreslå noen implikasjoner for fremtidig praksis innen involvering av etterlatte i hendelsesbaserte tilsyn av dødsfall dersom metoden ønskes innarbeidet.

- For å involvere etterlatte på en god måte, bør involveringsmetoden forankres i fylkesmannen kultur og arbeidspraksis.

- Arbeidsmetoden fremstår som mer ressurskrevende enn skriftlig informasjonsutveksling i saksbehandling, og må derfor innarbeides i planlegging og ressurssetting av tilsynsaktiviteter hos fylkesmannen.

- Involvering av etterlatte må være ledelsesforankret for å sikre god og lik gjennomføring, samt at tildeling av ressurser gjenspeiler den forventede arbeidsinnsatsen.

- Ved involvering av brukere i tilsynspraksis bør det legges til rette for større grad av dialog ettersom dette fører til en rikere mengde informasjon, som igjen betyr at konklusjonen i sakene blir gjort på grunnlag av et mer helhetlig bilde av hendelsesforløpet.

- Sterk ledelsesforankring av slike metoder for brukerinvolvering er essensielt for gjennomføringen ettersom tilsynsmyndigheter ikke har tradisjon for slik medvirkning.

- Praksis må også videreutvikle seleksjonskriterier knyttet til hvilke type saker som egner seg for en mer direkte dialog med involverte parter i de ulike tilsynssakene.

- Opplæring for å møte mennesker i krise, bør inngå som en forberedelse for involverte saksbehandlere.

- Møter med etterlatte etter uventede dødsfall kan være svært krevende kommunikasjonsmessig og møteleder bør ha betydelig erfaring med mennesker i sorg og krise, i tillegg til å ha inngående kunnskap innen helse og medisin.

- Fylkesmannen bør ha en bredde i medisinskfaglig kompetanse hos de involverte saksbehandlerne (leger) for å få kontinuitet i sakene slik at for eksempel legen med 
ansvar for oppfølging i kommunehelsetjenesten eller psykisk helse også deltar i møter for å unngå unødvendig overleveringer av informasjon i etterkant av møtet.

\section{Implikasjoner for forskning}

- Studere alternative metoder for hvordan tilsynsmyndigheter innhenter de etterlattes kunnskaper og perspektiver i hendelsesbaserte tilsyn.

- Studere hvilken betydning involvering av etterlatte har for konklusjoner som trekkes når saker anses som avsluttet.

- Studere hvilke spor man kan se igjen fra referanser til de etterlattes innspill i endelig rapport fra saksbehandlingen.

- Studere erfaringen de etterlatte har av møtet i etterkant av at sakene er konkludert.

- Studere tidsbruk i saksbehandling når etterlatte involveres, for å få kunnskap om noen saker avsluttes tidligere basert på informasjon fra etterlatte.

- Studere hvordan etterlatte selv ønsker å bli involvert i tilsyn og oppfølging av alvorlige hendelser.

- Studere en bred implementering av involveringstiltak for etterlatte nasjonalt og internasjonalt.

- Studere hvilke andre involveringstiltak av brukere og etterlatte som har hatt suksess $\mathrm{i}$ andre typer tilsyn utover uventede dødsfall for å kunne få ny kunnskap om proaktive, reaktive, individrettete, system rettede, direkte og indirekte måter å involvere brukere $\mathrm{i}$ tilsyn [23]. 


\section{Referanser}

1. Renedo, A., et al., Patient and Public Involvement in Healthcare Quality Improvement: How organizations can help patients and professionals to collaborate. Public Management Review, 2015. 17(1): p. 17-34.

2. Sutton, E., H. Eborall, and G. Martin, Patient Involvement in Patient Safety: Current experiences, insights from the wider literature, promising opportunities? Public Management Review, 2015. 17(1): p. 72-89.

3. Bouwman, R., et al., Is There a Mismatch Between the Perspectives of Patients and Regulators on Healthcare Quality? A Survey Study. Journal of Patient Safety, 2017. Published Ahead of Print

4. Bouwman, R., et al., Involving patients and families in the analysis of suicides, suicide attempts, and other sentinel events in mental healthcare: a qualitative study in the Netherlands. International Journal of Environmental Research and Public Health, 2018. 15(6): p. 1104.

5. Lippestad, J.W., Rapport: Følgeevaluering av prosjket Styrket involvering av pasienter, brukere og pårørende i tilsyn. 2018, SINTEF: Oslo.

6. Helse- og omsorgsdepartemantet, NOU 2015: 11 Med åpne kort, Oslo 2015.

7. Wiig, S., et al., Transparency in Health Care: Disclosing Adverse Events to the Public, in Risk Communication for the Future: Towards Smart Risk Governance and Safety Management, M. Bourrier and C. Bieder, Editors. 2018, Springer International Publishing: Cham. p. 111-125.

8. Helsetilsynet. Involvering av pasienter, brukere og pårørende i tilsyn. 2018; https://www.helsetilsynet.no/tilsyn/involvering-av-pasienter-brukere-og-parorende-itilsyn/].

9. Bergerød, I.J., et al., Next-of-kin involvement in improving hospital cancer care quality and safety - a qualitative cross-case study as basis for theory development. BMC Health Services Research, 2018. 18(1): p. 324

10. O'Hara, J.K., K. Aase, and J. Waring, Scaffolding our systems? Patients and families 'reaching in' as a source of healthcare resilience. BMJ Quality \&amp;amp; Safety, 2018. 28(1): p. 3.

11. Rutz, S., et al., Inspectors' responses to adolescents' assessment of quality of care: a case study on involving adolescents in inspections. BMC Health Services Research, 2018. 18(1): p. 226.

12. Adams, S., H. van de Bovenkamp, and P. Robben, Including citizens in institutional reviews: expectations and experiences from the Dutch Healthcare Inspectorate. Health Expectations, 2013. 2013(18): p. 1463-1473.

13. Haraldseid, C., L. Schibevaag, and S. Wiig. Involvement of the bereaved in supervisory investigation of severe adverse events: A literature review. in NSQH 2018. Copenhagen NSQH Proceedings

14. Patton, M., Qualitative research and evaluation methods 2002, Thousand Oaks: Sage.

15. Braun, V. and V. Clarke, Using thematic analysis in psychology. Qualitative Research in Psychology, 2006. 3(2): p. 77-101.

16. Kok, J., I. Leistikow, and R. Bal, Patient and family engagement in incident investigations: exploring hospital manager and incident investigators' experiences and challenges. Journal of Health Services Research \& Policy, 2018. 23(4): p. 252-261.

17. Doyle, C., L. Lennox, and D. Bell, A systematic review of evidence on the links between patient experience and clinical safety and effectiveness. BMJ Open, 2013. 3(1): p. e001570.

18. Wiig, S., Contributions to risk management in the public sector, in Social Sciences 2008, University of Stavanger: Stavanger.

19. Wiig, S. and K.J.S.s.m. Aase, Fallible humans in infallible systems? Learning from errors in health care. 2007. 11(3): p. 1-13.

20. Wiig, S. and G.S. Braut, Developments in analysis of adverse events in Healthcare - policy and practice in Norway. I: Prevention of Accidents at Work. CRC Press, 2018: p. 39-45.

21. Ocloo, J.E., Harmed patients gaining voice: challenging dominant perspectives in the construction of medical harm and patient safety reforms. Soc Sci Med 2010. 71(3): p. 510-516. 
22. Carel, H. and I.J. Kidd, Epistemic injustice in healthcare: a philosophial analysis. Med Health Care and Philos, 2014. 17: p. 529-540.

23. Tritter JQ. Revolution or evolution: the challenges of conceptualizing patient and public involvement in a consumerist world. Health Expect. 2009, 12(3):275-87.

24. Richardson et al. User involvement in regulation: A qualitative study of service user involvement in Care Quality Commission inspections of health and social care providers in England. Health Expectations. 2018:1-9. 